\title{
Tectono-sedimentary evolution of the Pliocene to Lower Pleistocene succession of the Apricena-Lesina-Poggio Imperiale quarrying district (western Gargano, southern Italy)
}

\author{
Giulio Pavia (*), Carlo Bertok $(*)$, Giuliano Ciampo (**), Valentino Di Donato (**), Luca Martire (*), \\ Federico Masini $(* * *)$, Marco Pavia $(*)$, Nicoletta Santangelo $(* *)$, Emma Taddei Ruggiero $(* *)$ \& Marta Zunino $(*)$
}

\section{ABSTRACT}

The post-Miocene marine succession of the "Apricena horst» is described with the purpose to verify the chronostratigraphic constraints for the type-locality of the Pirro Nord Faunal Unit. The stratigraphic succession has been subdivided in four units bounded by ubiquitous unconformities with evidence of subaerial exposure. The two basal units (dated late Zanclean to at most early Piacenzian) are formally grouped in the Lago di Varano Fm. that on the whole consists of sediments ranging from lagoonal to circalittoral environments. Within the lowermost unit, a megabreccia is interpreted as the product of a tsunami event. The third unit, Gelasian in age, is informally cited as Calcari a Briozoi Fm. The last unit, the Lower Pleistocene Serracapriola Fm., consists of siliciclastic deltaic sediments and represents the closure of the marine cycle. Conspicuous lateral facies and thickness changes, and the frequency of unconformities are the consequence of an intense synsedimentary tectonic activity developed in the frame of the southern Apulia foredeep closure. In the study area, such activity is documented by two E-W trending normal faults which, during Zanclean and at least the earliest Gelasian, controlled the Pliocene horst-graben system of the Apricena-Poggio Imperiale area.

KEY WORDS: Facies analysis, Synsedimentary faulting, Ecobiostratigraphy, Tsunami event, Pliocene, Pirro Nord, W Gargano.

\section{RIASSUNTO}

Evoluzione tettono-sedimentaria della successione pliopleistocenica del distretto estrattivo Apricena-Lesina-Poggio Imperiale (Gargano occidentale, Foggia, Italia meridionale).

La successione marina post-miocenica dello «horst di Apricena» è stata analizzata con la finalità di verificare la validità del vincolo cronostratigrafico già accreditato in letteratura al Pleistocene inferiore per la località-tipo della Unità Faunistica Pirro Nord nel Villafranchiano superiore. Le facies e le associazioni fossili dell'intera successione sono state studiate in 9 sezioni distribuite lungo il rilievo morfo-strutturale esteso in senso E-W da Apricena a Poggio Imperiale; i risultati hanno permesso di definire le condizioni paleoambientali e di caratterizzare cronologicamente le diverse unità stratigrafiche. Le attuali ampie esposizioni nelle cave di coltivazione della "Pietra di Apricena» (Calcare di Bari Fm.) hanno portato a costruire uno schema deposizionale e paleostrutturale innovativo rispetto a quello presente in letteratura (CASOLARI et alii, 2000).

Il record stratigrafico è stato suddiviso in tre formazion delimitate da superfici di discontinuità ubiquitarie. La Formazione

(*) Dipartimento di Scienze della Terra, Università di Torino, Italy (giulio.pavia@unito.it).

$(* *)$ Dipartimento di Scienze della Terra, Università di Napoli, Italy (valedido@unina.it).

$(* * *)$ Dipartimento di Scienze della Terra, Università di Paler-

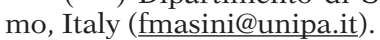

del Lago di Varano, datata al tardo Zancleano - (?) Piacenziano inferiore, poggia sulle Terre Rosse residuali di età messiniana-pliocenica o direttamente sulla superficie incarsita dei calcari mesozoici della Fm. del Calcare di Bari. La parte inferiore di questa formazione comprende tre litozone (limestone-clay ltz., calcarenite ltz., megabreccia ltz.): le prime due testimoniano una trasgressione con transizione da facies lagunari a infralitorali; la litozona di megabreccia è interpretata come il risultato deposizionale di uno tsunami. La parte superiore della Formazione di Varano, al di sopra di una discontinuità con evidenze di esposizione subaerea, comprende sei litozone (Isognomon biostromal ltz., barnacle-coral biostromal ltz., barnaclecoral biostromal breccia ltz., barnacle horizon, barnacle-bearing ltz., Glycymeris-bearing ltz.) i cui rapporti geometrici e le rapide variazioni di spessore riflettono irregolarità paleotopografiche del fondale e variazioni del tasso di sedimentazione. La Formazione dei Calcari a Briozoi, datata al Piano Gelasiano, poggia su un'altra superficie di discontinuità; le biofacies ad alghe corallinacee, invertebrati (briozoi, brachiopodi, pelecipodi) e microfossili (foraminiferi, ostracodi) attestano la transizione da ambienti circalitorali all'infralitorale superiore. La Formazione di Serracapriola ha come limite inferiore una marcata superficie erosiva ed è costituita da depositi silicoclastici di fan-delta con apporto dai quadranti nord-occidentali; essa è databile al Gelasiano superiore (?) - Pleistocene inferiore e rappresenta la chiusura del ciclo marino ovest-garganico. I cambiamenti di facies, le variazioni di spessori stratigrafici e la presenza di superfici di discontinuità, spesso corrispondenti a paleoscarpate, sono espressione di un'intensa tettonica sinsedimentaria, attiva a partire dallo Zancleano e fino all'inizio del Gelasiano, che ha prodotto le due faglie E-W bordiere dello horst di Apricena. Geometrie e sviluppo di queste faglie e delle rispettive antitetiche vengono descritte in dettaglio, così come le caratteristiche geometriche e sedimentologiche delle litozone che ne colmano i relativi depocentri o che le sigillano. Dopo l'emersione pleistocenica, la fascia di fratturazione della faglia meridionale ha subito incarsimento; i depositi di fessura hanno restituito abbondanti fossili della Unità Faunistica Pirro Nord (ABBAzzı et alii, 1996) e, recentemente, numerosi manufatti litici attestanti una presenza umana nel Pleistocene inferiore (ARZARELlo et alii, 2007, 2009), la più antica sinora documentata in Europa.

TERmini CHIAVE: Analisi di facies, Tettonica sinsedimentaria, Ecobiostratigrafia, Tsunami, Pliocene, Pirro Nord, W Gargano.

\section{INTRODUCTION}

The present work arises from the necessity to verify, as precisely as possible, the chronological constraints to the well known vertebrate type-assemblage of the Faunal Unit Pirro Nord, within the late Villafranchian Mammal Age (DE GiUli et alii, 1987a; ABBAzzi et alii, 1996; GLIOZZI et alii, 1997, and references therein). The interest on the continental fossiliferous deposits from the formerly Pirro Nord locality, within the Apricena-LesinaPoggio Imperiale quarrying district, recently revived after 


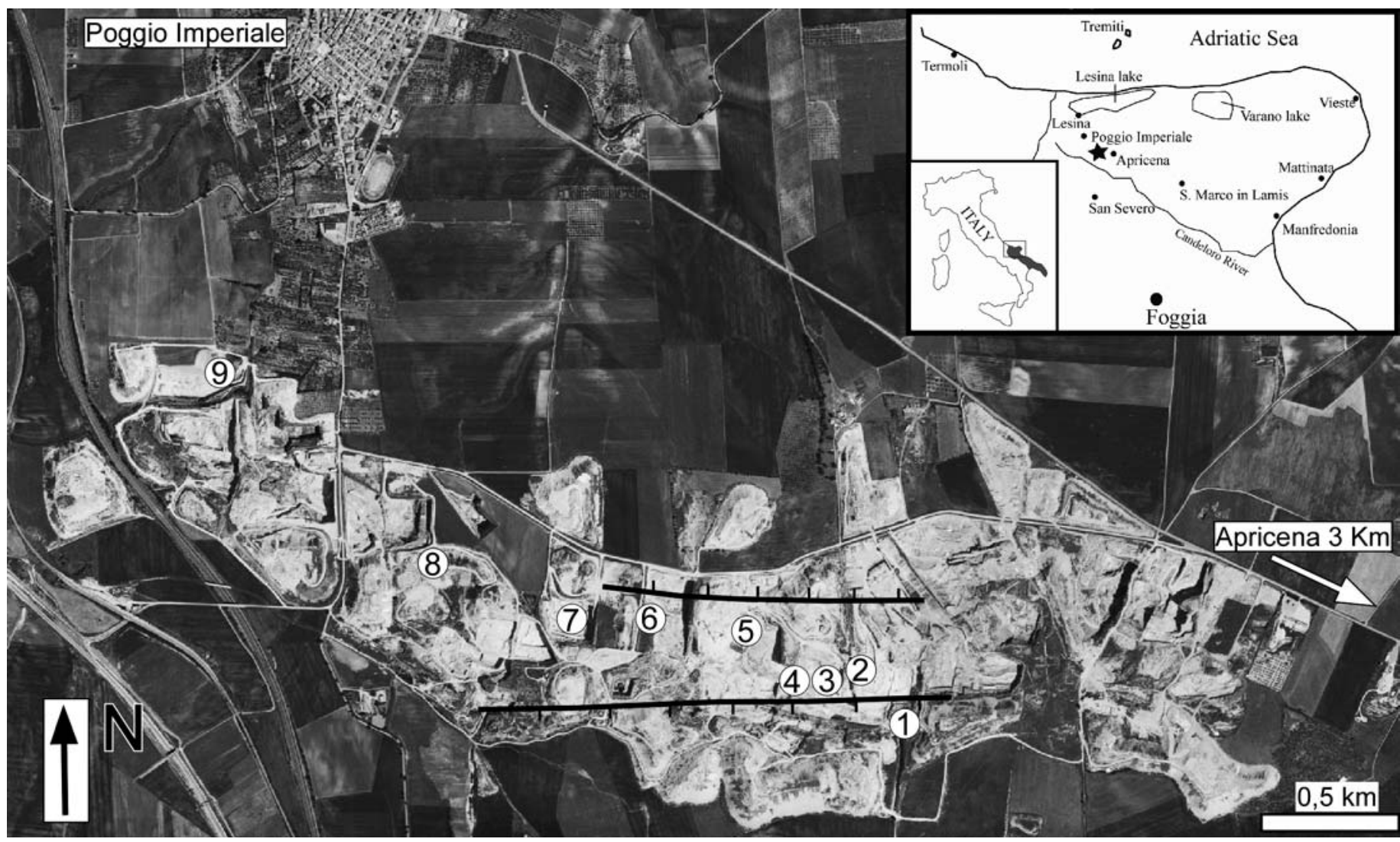

Fig. 1 - Geographic location and aerial photograph of the Apricena horst. Numbers 1-9 refer to the measured stratigraphic sections. Black lines are the traces of faults bordering the Apricena horst.

- Posizione geografica e foto aerea dello horst di Apricena. I numeri indicano la posizione delle sezioni stratigrafiche misurate. Le linee nere approssimano le tracce delle faglie bordiere dello horst di Apricena.

discovery of lithic tools associated with such vertebrate assemblages in the fillings of an extensive karst network, that document the human occurrence in southern Italy in the Early Pleistocene. These flint artefacts testify that the genus Homo spread in Europe earlier than previously supposed, in the Matuyama post-Olduvai palaeomagnetic Chron, between 1,3 and 1,7 Ma in Early Pleistocene (Arzarello et alii, 2007; Pavia et alii, 2008). The recent quarry works have exposed larger transects of the Pliocene to Lowermost Pleistocene stratigraphic succession in which the fossiliferous karst structures are developed. The stratigraphic architecture, the structural-depositional interpretation and the regional correlation result to be quite different from those discussed even in recent papers (CASOLARI et alii, 2000, and references therein).

Given the importance of this site, a revision of its stratigraphy was needed and has been carried out in this paper. In particular, we have focused our studies on the lithostratigraphic organisation of that succession and on the palaeoecologic and chronostratigraphic characterisation of the depositional units by palaeobiological records. Their relationships were controlled by an active Pliocene synsedimentary tectonics related with the Neogene closure of the Apulia foredeep. Our aim is thus twofold, namely to confirm the Earliest Pleistocene constraint to the type Pirro Nord F.U., and to detail the evolution of the northwestern Gargano Pliocene succession which pertains to the eastern offshoot of the "Fortore High", once described as a W-E regional element produced by the extensional tectonism that during Pliocene separated the northern Molise Basin from the southern Puglia Basin (CASNEDI, 1988; RICHETTI et alii, 1992; CAPUANO et alii, 1996; Robustelli \& Aucelli, 2001; Spalluto \& MORETTI, 2006).

\section{STRATIGRAPHIC AND STRUCTURAL SETTING}

The studied quarries are located north-west of the Gargano Promontory on a E-W elongated topographic belt, comprised between Apricena and Poggio Imperiale (figs. 1, 2) and slightly elevated on the surrounding coastal plain of the Lesina Lake; it constitutes the socalled Apricena horst, a positive structure uplifting since Late Miocene and connected to E-W to WNW-ESE trending regional faults, whose related historical sismicity has been documented by several authors (GUIDOBONI \& Tinti, 1988; Tinti \& Piatanesi, 1996; Tondi et alii, 2005; PicCARdi, 2005). PATACCA \& ScANDONE (2004) suggested that the causative structure of the 1627 Gargano earthquake, the largest historical event with a macroseismic magnitude of 6.73 , is a normal fault named Apricena Fault trending WNW-ESE for a length of about $30 \mathrm{~km}$ and with a cumulative displacement of about $500 \mathrm{~m}$. The Apricena Fault is the westernmost branch of the Mattinata fault system, a complex crustal-scale E-W trending wrench zone crossing the whole southern Gargano promontory and continuing offshore in the Adriatic sea 


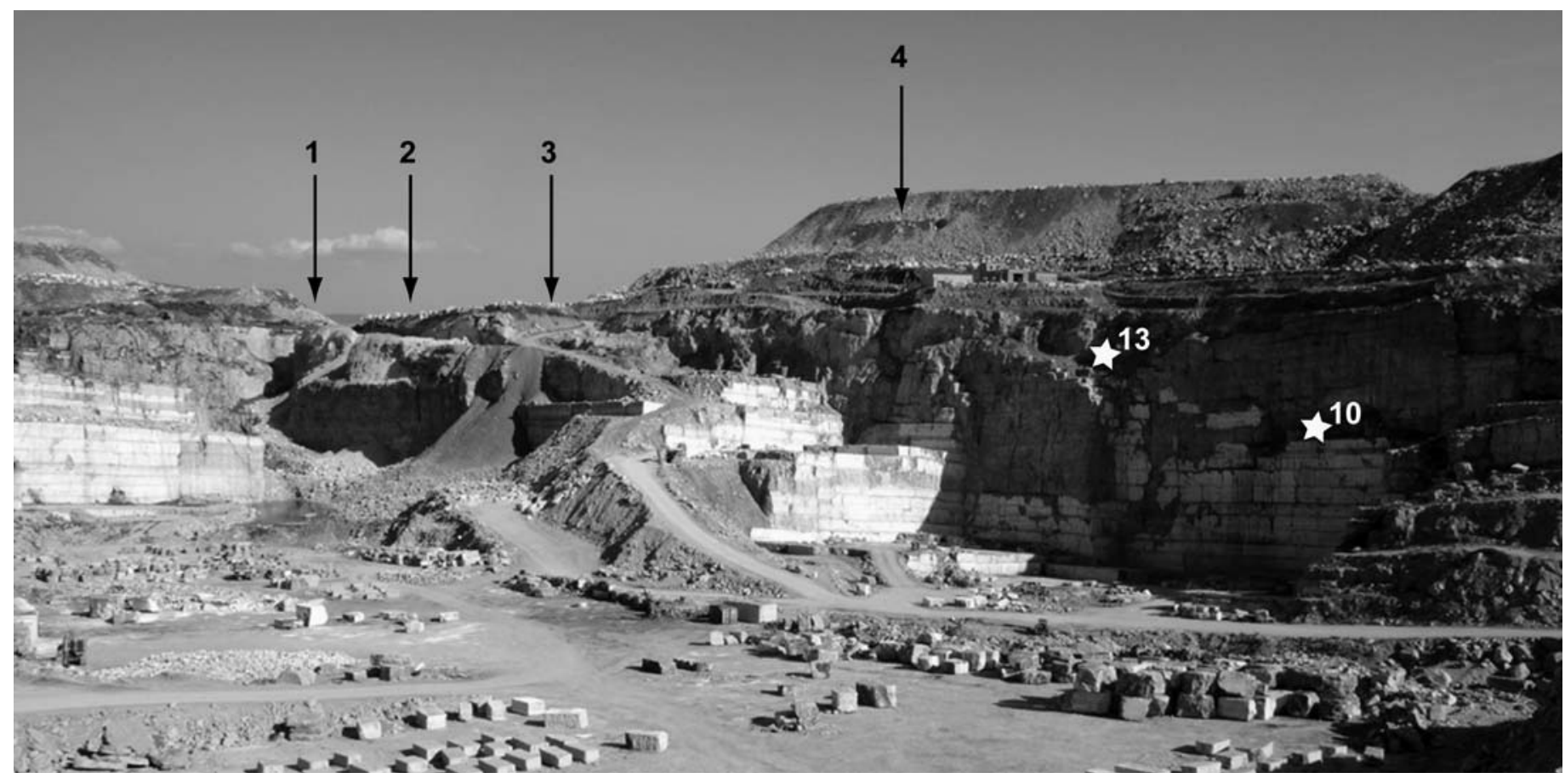

Fig. 2 - Very recent picture of the southern side of the Dell'Erba quarrying complex, former Pirro Nord quarries. Numbered asterisks mark the position of the palaeontological-anthropological diggings at Pirro 10 and Pirro 13, exploited since 2007. Location of sections 1-4 is reported. - Immagine recente del settore meridionale del complesso di cave Dell'Erba, ex-cave Pirro Nord. Gli asterischi numerati ubicano gli scavi paleontologico-antropologici di Pirro 10 e Pirro 13, iniziati nel 2007. I numeri 1-4 indicano la posizione delle sezioni da 1 a 4 descritte nel testo.

for more than $130 \mathrm{~km}$. The apparent controversy about its kinematic behaviour (PATACCA \& SCANDONE, 2004, and references therein) arised mainly from its long-lasting polyphasic history: according to CHILOVI et alii (2000), a first Late Miocene to Early Pliocene phase of sinistral strike slip related to the paroxysmal orogenic shortening of Southern Apennines was followed by a second Late Pliocene to present day phase of dextral strike slip. BRANCKMAN \& AYDIN (2004) proposed that the interaction with another E-W trending left-lateral strike-slip fault zone bounding the Gargano to the North caused the uplift of the Gargano area since Late Miocene. Such a tectonically active setting deeply influenced the evolution of the Neogene stratigraphy, controlled by a complex pattern of structural highs and lows.

Consequently, the Neogene succession in north-western Gargano is extremely complex due to the local palaeotopography controlled by tectonic activity, alternatively extensional and compressional (ABBAZZI et alii, 1996), that produced palaeoenvironments repeatedly changing in space and time. Furthermore, the combination of climatic-eustatic fluctuations and tectonic structures produced unconformities of different orders and thus marked facies variations. The expression of such a complexity is the different interpretation of lithostratigraphic units, from time to time referred to as Miocene or Pliocene (e.g. BONI et alii, 1969; CREMONINI et alii, 1971; D'AlESSANDRO et alii, 1979; CAPUANO et alii, 1996; CASOLARI et alii, 2000).

In short, during the Miocene a marine sedimentation, although irregular and discontinuous, took place in the Gargano area (D'AlESSANDRo et alii, 1979; BosELLINI \& NERI, 1995; BosEllini et alii, 1994; CASOlARI et alii, 2000), while the Apricena-Poggio Imperiale block formed a structural and subaerial emerged high elongated in E-W direction. During the Pliocene the Gargano Promontory was uplifted and became an elongated island whereas the Apricena horst subsided and was flooded.

The Plio-Pleistocene marine succession cropping out in the quarrying district westwards of the Apricena town is composed of carbonate to siliciclastic terms unconformably resting on the Mesozoic limestones of the Calcare di Bari Fm. (Spalluto \& Pieri, 2008). Two sets of continental deposits also occur: the residual Terre Rosse characterized by the Late Miocene to Early Pliocene "Mikrotia fauna», and the sandy pelites of the Early Pleistocene Pirro Nord Fauna Unit (see next chapter for details). The Plio-Pleistocene marine succession, after a short reference by D'ALESSANDRO et alii (1979), was first investigated in detail by VALLERI (1984) and deeply revised by ABBAzzI et alii (1996). Further contributions derive from the analyses on the siliciclastic unit by CAPUANO et alii (1996) and the regional synthesis by CASOlARI et alii (2000). In particular, ABBAzzi et alii (1996) distinguished seven lithostratigraphic units synthesized from eight quarry outcrops; important thickness changes at all levels of the succession document the fundamental role of tectonics in creating a rugged topography with a narrow horst flanked by more subsiding areas (ABBAzzI et alii, 1996, fig. 3).

Field observations by ABBAzzI et alii (1996) were carried out in a scenario that was deeply different compared with the present one, and in this respect it is sufficient to compare the two pictures of fig. 3 respectively taken in 1991 and 2006. More quarries, larger outcrops, deeper excavations, complementary transects, easier access to the quarry walls, different stratigraphic approach allowed us to describe an unexpectedly complex stratigraphy and 

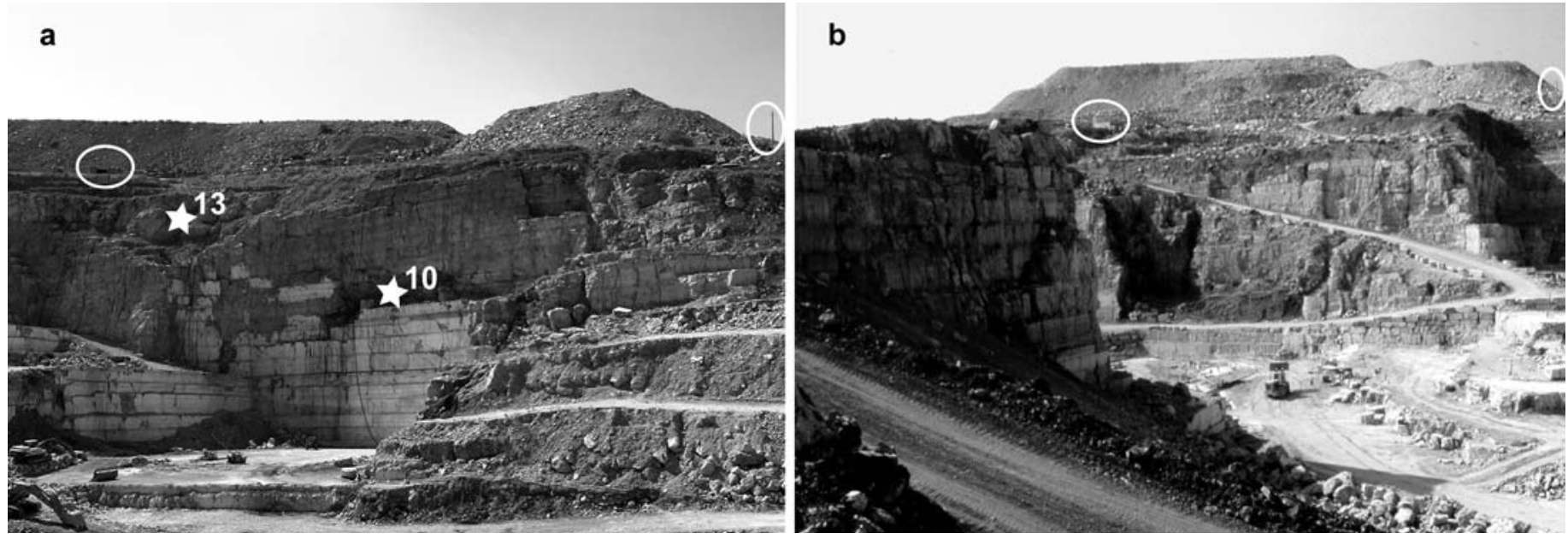

Fig. 3 - (a) Frontal view of Gaetano Dell'Erba quarry wall in 2006; (b) The same quarry wall in 1991: note the left work cabins and the right electric post (white circles) on the Holocene field-plane for comparisons.

- (a) Vista frontale del fronte della cava Gaetano Dell'Erba nel 2006; (b) Lo stesso fronte di cava nel 1991: si noti sul piano campagna olocenico la posizione dei capanni a sinistra e del palo dell'elettricità a destra (cerchi bianchi) per i confronti.

to interpret in a new way the complex relationships among the Plio-Pleistocene marine units. The lithostratigraphic description summarized in the following chapters is the synthesis of both original field studies and data derived from literature.

\section{CONTINENTAL DEPOSITS AND FAUNAS}

The interest on the continental deposits of the Gargano, and in particular of the Apricena-Poggio Imperiale area, raised in the sixties of the past century owing to the widespread occurrence of karstic pockets very rich in fossil contents. The first report is by FREUDENTHAL (1971) who pointed out the occurrence of a very diversified Miocene-Pliocene endemic fauna from the Terre Rosse fissure infillings, and also the occurrence in some quarries of younger not endemic faunas "with Allophaiomys". Both continental deposits are preserved in morphological traps (karst structures) that are very widespread in the area. Two cycles of continental deposition, of unequal duration and spatial extension, are recorded: an older polyphasic and longer cycle (palaeokarst), and a younger cycle (neokarst) that is localized in the easternmost Apricena horst.

\section{THE ENDEMIC FAUNAS FROM THE TERRE RosSE}

The Terre Rosse fossil assemblages are also known as the Mikrotia fauna named by the ubiquitous occurrence of the very peculiar endemic murid Mikrotia. These fossil assemblages include mammals (mostly small mammals), birds, reptiles and amphibians and document the population of a strongly isolated endemic district, possibly an island in an archipelago (see MASINI et alii, 2008, with references therein). According to ABBAzZI et alii (1996) the karst sediments that contain the endemic mammal remains are derived by soils (oxisoils) some relics of which are still preserved in the Apricena horst, buried by marine deposits. The sediments fill in an extensive karst system developed within Mesozoic carbonates. The palaeokarst formed during a very long phase of emersion and is represented by well developed superficial morphologies that are the result of repeated dissolution activities (ABBAzZI et alii, 1996). Hypogene cavities are not observable and the morphologies are shallow depressions (possibly sinkholes) and, much more commonly, fractures of moderate depth (maximum some tens of meters) oriented along the main tectonic directions and enlarged by dissolution. The network likely developed under a cover of residual deposits during a phase of relatively stable climatic and tectonic conditions (ABBAzZI et alii, 1996).

During the time interval documented by the fissure deposits, the faunal diversity changed and several taxa underwent significant evolutionary changes and radiations. On the basis of their fossiliferous content, the fissure infillings can be arranged in a chronological sequence that includes at least four phases characterized by different taxonomical composition and evolutionary stage (Freudenthal, 1976; DE GiUli et alii, 1987b, 1990). More than forty years after their discovery, the Mikrotia fauna still does not have a firmly established age. Nowadays the range of possible ages for this fauna is fairly constrained and a Messinian-Early Pliocene age is considered suitable by several authors (e.g. MAzzA \& RUSTIONI, 2008).

The Mikrotia fauna is not limited to the Apricena-Poggio Imperiale area, and some outcrops have been described from other locations at the base of the Gargano Mount (e.g. San Nazario, Monte Granata) or even in the Trani Area (FREUDENTHAL, 1971), thus indicating that the insular domain had a consistent palaeogeographical extent. The occurrence of some faunal elements (namely Hoplitomeryx and Deinogalerix, but unfortunately no small mammals) at Scontrone locality (Maiella Mountain) in coastal sediments dated to the early Tortonian (Rustioni et alii, 1993; MAzZA \& Rustioni, 1996, 2008) is particularly significant, and confirms that the Gargano was a part of a wide system of isolated lands, characterised by a peculiar endemic fauna, that has been named as the Abruzzo-Apulia domain or bioprovince. The younger age of the Gargano fissures compared with Scontrone could be explained assuming that the Gargano 
palaeo-islands actually represented a late relic of stable isolated lands, that were still in existence after the Scontrone Area was submerged and involved in the Apennine building (Rook et alii, 1999, 2006; MASINI et alii, 2008).

\section{THE LATE VILLAFRANCHIAN FAUNA}

The continental stratigraphical record in the study area is discontinuous because of the marine depositional phase that separates the endemic faunas from the successive not endemic vertebrate ones. The latter are collectively known as the "Pirro Nord Local Fauna» and are composed of taxa which do not have any relationship with the Terre Rosse faunas.

Fossils are found in silty-sandy sediments that fill in the cavities of the neokarst cycle, and mostly occur in a very restricted area. Karstic features include both superficial (e.g. sinkholes) and hypogene forms, and were opened within the Pliocene cover, along the boundary between the Pliocene cover and the Mesozoic limestones of the Calcare di Bari Fm., and even within the Calcare di Bari Fm. itself (ABBAZZI et alii, 1996). In some locations (e.g. Cava Dell'Erba) the neokarst reactivated the older palaeokarst morphologies that were locally emptied out of the Terre Rosse sediments, thus forming a rather complex net of hypogeal fissures (ABBAzzI et alii, 1996). The infillings of the resulting network very frequently contain Early Pleistocene (late Villafranchian) vertebrate fossils.

After a short quotation by FREUDENTHAL (1971), DE GIULI \& TORRE (1984) is the first paper where the small mammal findings from a fissure named as Pirro Nord are described. In 1985 the new fossil assemblage (large and small mammals) was communicated to the scientific community at the Fifth Palaeontological Colloquium in Weimar and a report was then published by DE GIULI et alii (1987a). In few years the fauna gained more and more importance and the former Pirro Nord quarry was proposed (and accepted) as the type locality of the youngest faunal unit of the late Villafranchian (macro-) Mammal Age (Pirro Nord F.U.): i.e. it was considered as representative of a distinct phase of mammalian population of the Italian peninsula (GLIOzZI et alii, 1997). Meanwhile, new studies were carried out and new fossil material was recovered (ABBAZZI et alii, 1996, with references therein). An updated faunal list is in ARZARELlo et alii (2009).

The dating of the Pirro Nord fauna is biochronological. The macro-fauna includes several taxa that also occur in older Italian late Villafranchian localities (e.g. Pietrafitta, Cava Liberatori) referred to the Farneta F.U., the biochronological unit just preceding the Pirro Nord F.U. However, at Pirro Nord some new taxa are found, which also occur in localities definitely younger; the best known taxon is Bison (Eobison) degiulii which is absent within the Farneta F.U. (GLIOZzI et alii, 1997; MASINI \& SALA, 2007). Another element for biochronological dating is the vole Allophaiomys ex gr. ruffoi (MASINI et alii, 1998) which is indicative of the early Biharian (micro-) Mammal Age (cf. Gliozzi et alii, 1997; SALA \& MASINI, 2007). In synthesis, the Pirro Nord F.U. is considered as younger than the Farneta F.U. and older than the Colle Curti F.U. of the earliest Galerian Mammal Age (cf. MASINI \& SALA, 2007, with references therein). In terms of magnetostratigraphy the Pirro fissure infillings should be considered definitely younger than the Olduvai and older than the Jaramillo submagnetochrones (MASINI \& SALA,
2007). The Pirro Nord faunal characteristics show no signal of insular endemism. This observation, coupled with the occurrence of a well developed trophic net, evidences that at the time of the neokarst infillings the Gargano area should definitely have been in full geographical connection with the Italian peninsula.

\section{THE PLIOCENE TO LOWER PLEISTOCENE LITHOSTRATIGRAPHY}

The Plio-Pleistocene marine succession that presently crops out in the Apricena to Poggio Imperiale quarry field is arranged in two lithologic bodies separated by a discontinuity: a lower carbonate complex and an upper siliciclastic unit. In turn, the carbonate complex may be subdivided in two superposed units. CAPUANO et alii (1996) assigned the carbonate complex to the Calcareniti di Apricena Formation that however does not crop out in the studied sector and is older (Middle Miocene) as evidenced by CREMONINI et alii (1971) and D'ALESSANDRO et alii (1979). D'ALESSANDRO et alii (1979) and CASOLARI et alii (2000), instead, referred the whole carbonate complex to the Calcarenite di Gravina Formation. This formation, however, represents the Pleistocene transgressive depositional phase well known in the southernmost Apulia region, i.e. very far from Gargano Promontory (AzzAROLI, 1968; MASSARI et alii, 2001); actually, its bio- and lithofacies correspond only with the upper unit of the Pliocene carbonate complex, whereas the lower unit markedly differs from the Gravina Formation and shows so peculiar features to need formal distinction. Similarities exist by converse with the Middle Pliocene Lago di Varano Formation that was proposed by CREMONINI et alii (1971) for the Sheet 156 "San Marco in Lamis» of the Italian Geological Map; the Pliocene age of this formation was then confirmed by ABBAzzI et alii (1996). The upper unit of the carbonate complex, rich in remains of colonial briozoans, may instead fit with the Calcari a Briozoi Formation proposed by Merla et alii (1969) for the Sheet 164 «Foggia» of the Italian Geological Map and wrongly referred to Middle (?) Miocene, as evidenced later on by D'ALESSANDRO et alii (1979) who documented its mid-Pliocene age.

Some authors proposed to abandon both Lago di Varano Fm. and Calcari a Briozoi Fm. terms (D'ALESSANDRO et alii, 1979; PAMPALONI, 2001) and to include all the Pliocene carbonate deposits of the Gargano area in the Calcarenite di Gravina Formation. However, literature does not demonstrate any regional continuity of the latter unit from its type-locality to the Gargano area, located more than $200 \mathrm{~km}$ to the north. Moreover, in the absence of a revision of the regional lithostratigraphy, it seems better to evidence local stratigraphic and sedimentological peculiarities. For this reason, within the carbonate complex we distinguish two lithostratigraphic units with formational meaning: the Lago di Varano Fm. for the lower part, and the Calcari a Briozoi Fm. for the upper part.

The Pliocene-Pleistocene succession, at last, ends with siliciclastic silty-sand deposits referred to the Serracapriola Formation. This lithostratigraphic unit was proposed by BoNI et alii (1969) for the Sheet 155 «San Severo» of the Italian Geological Map, and referred to Pliocene to Early Pleistocene (see also CAPUANO et alii, 1996). For the Sheet 156 "San Marco in Lamis» CREMONINI et alii (1971) restricted the age to Late Pliocene. 


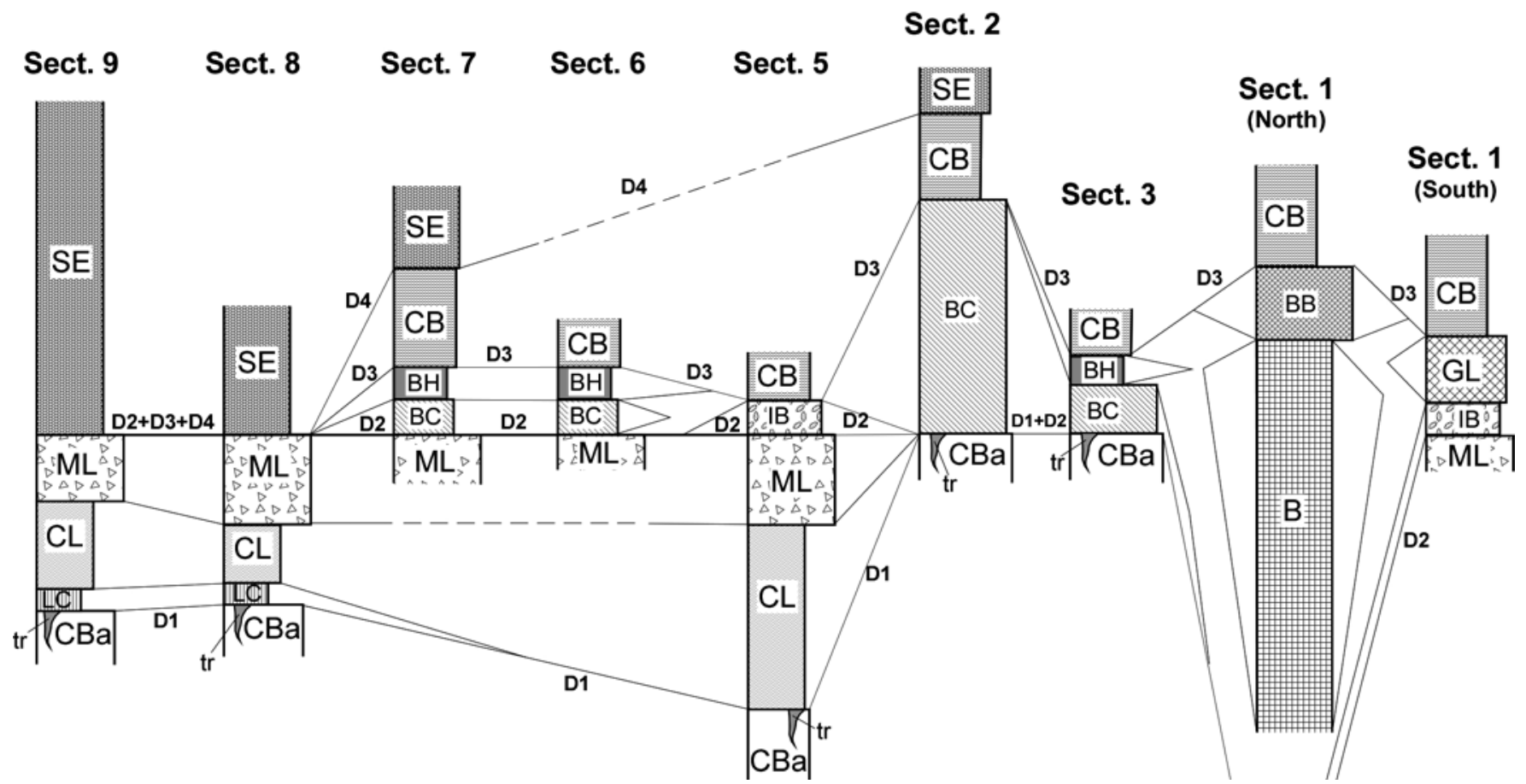

Fig. 4 - Lithostratigraphic logs of sections 1-9 described in the Apricena quarrying district (see fig. 1 for location). D1-D4, unconformity surfaces. Correlation plane at the unconformity D2.

- Log litostratigrafici delle sezioni 1-9 descritte nel complesso estrattivo di Apricena-Lesina-Poggio Imperiale (vedi fig. 1 per ubicazione). D1-D4, superfici di discontinuità. Il piano di correlazione è posto alla discontinuità D2.

- B, barnacle-bearing lithozone. BB, barnacle-coral biostromal breccia lithozone. BC, barnacle-coral biostromal lithozone. BH, barnacle horizon. CB, Calcari a Briozoi Fm. CBa, Calcare di Bari Fm. CL, calcarenite lithozone. GL, Glycymeris-bearing lithozone. IB, Isognomon biostromal lithozone. LC, limestone-clay lithozone. ML, megabreccia lithozone. SE, Serracapriola Fm. tr, Terre Rosse. Thicknesses of BC, $\mathrm{BH}, \mathrm{LC}$ and IB are not on scale.

The Apricena quarrying district succession was described, sampled and correlated in nine sections cropping out in adjacent quarries located in an area of around $1.5 \mathrm{~km}^{2}$ (figs. 1, 4). The following ones approximately correspond to the sections studied by ABBAzzI et alii (1996): 1 to 8,5 to $6+7,6$ to 5,7 to 4,8 to $1+2$. Sections 2 , $3,4,9$ are new and add important information to supplement the stratigraphy of this sector. A large amount of data has been elaborated on invertebrate and microfossil assemblages, brachiopods, molluscs, foraminifers and ostracods; they allow fine biostratigraphic and palaeoenvironmental definitions of the units described in the following pages. The planktonic foraminifera biostratigraphy refers to the zonation of CITA (1975), emended by SPROVIERI $(1992,1993)$, whereas benthic foraminifer taxonomy mainly follows SGARRELla \& MONCHARMONTZEI (1993).

\section{LAGO DI VARANO FORMATION}

Nine lithozones have been distinguished within the Lago di Varano Fm. on the basis of their facies associations and palaeontological content.

\section{Limestone-clay lithozone}

It is composed of medium to thick limestone beds alternating with thin to medium clay beds. Carbonate beds consist of whitish to locally reddish mudstones with rare small gastropods and ostracods, occasionally filled with calcite drusy cements; very thin and irregular fissu- res, possibly related to plant roots, cross the beds (fig. 5). Clay beds consist of bioturbated greenish clays with scattered $\mathrm{cm}$-large limestone clasts. This lithozone has been observed uniquely in sections 8 and 9. It lies on an erosional surface cutting the Miocene Terre Rosse and the Calcare di Bari Fm. with a marked angular unconformity; its maximum thickness is about 1 metre, but it is highly irregular and discontinuous, deeply controlled by the jagged morphology of the stratigraphic top of Calcare di Bari Fm. (fig. 6).

The limestone-clay lithozone corresponds to the «transgressive system» of CAPUANO et alii (1996) and marks the recovery of sedimentation in a transitional lagoonal environment, with periodic episodes of subaerial exposure.

\section{Calcarenite lithozone}

It is composed of well-sorted fine- to coarse-grained peloidal and bioclastic grainstones. Bioclasts consist of small gastropods and pelecypod fragments plus rare benthic foraminifera in the fine-grained levels, miliolids and ostracods in the coarser-grained ones. They are mainly organized in medium to thick beds showing a parallel lamination or a ripple cross-bedding (fig. 7) alternating with subordinated coarser-grained thin to medium beds. The latters show a thinning upward trend and are characterized by erosional bases and locally by a normal graded bedding with $\mathrm{mm}$ - to $\mathrm{cm}$-thick lime mudstone intraclasts, referable to the underlying limestone-clay lithozone, concentrated in the lower part of beds. Intergranular pore- 


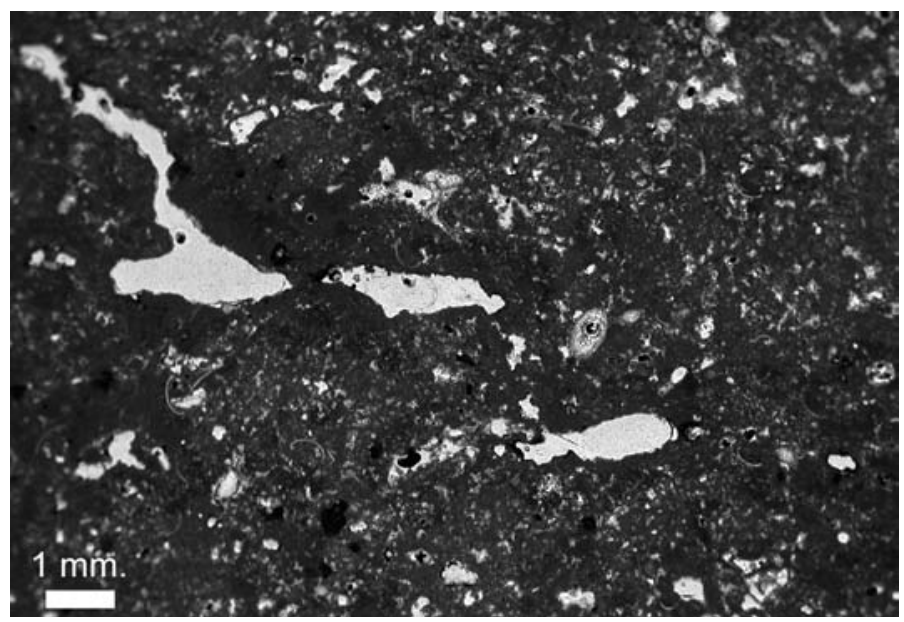

Fig. 5 - Photomicrograph showing the vuggy structure within a carbonate bed of the limestone-clay lithozone. Largest vugs are possibly related to the former occurrence of plant roots.

- Microfotografia di un livello carbonatico della limestone-clay lithozone. Si noti la struttura vacuolare; $i$ pori più grandi sono riferibili alla originaria presenza di resti vegetali nel sedimento.

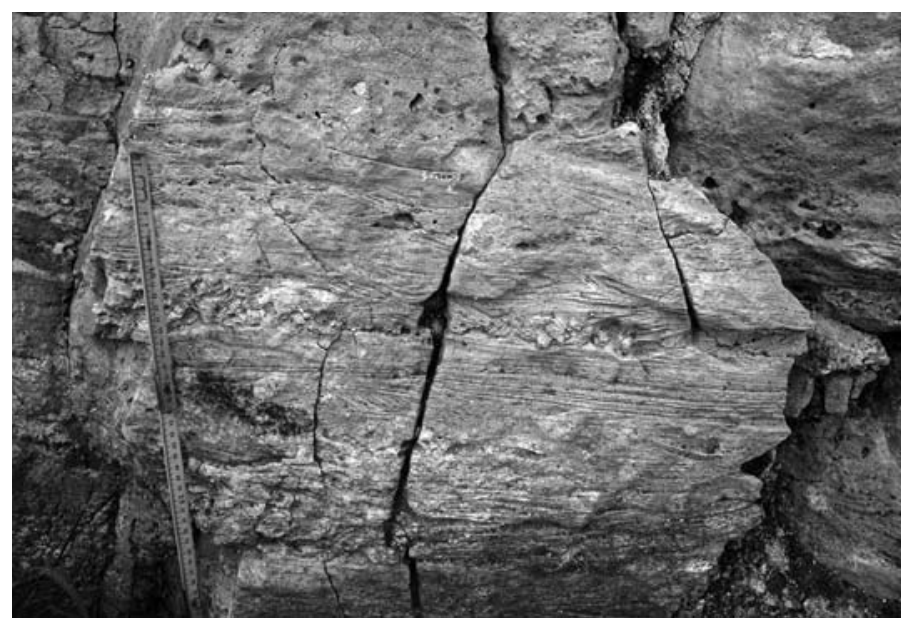

Fig. 7 - Parallel lamination and small-scale trough cross-bedding within the calcarenite lithozone at section 8 .

- Laminazione parallela e laminazione incrociata a piccola scala entro la calcarenite lithozone nella sezione 8.

filling cements consist of sparry calcite with a drusy fabric that suggest early diagenesis in a meteoric phreatic environment. This lithozone has been observed in sections $5,6,7,8,9$, but it has been directly measured only in sections 5 and 8. Its thickness ranges from 2.7 (section 5) to $8.4 \mathrm{~m}$ (section 8 ). Section 5 shows this unit directly lying on the stratigraphic top of the karstified Calcare di Bari Fm., whereas in section 8 it rests with erosional contact on the limestone-clay lithozone.

The calcarenite lithozone corresponds to the facies 3a, unit 3, of ABBAZZI et alii (1996), and indicates the transition to an open marine setting after the first phase of transgression represented by the limestone-clay lithozone. More in detail, the bioclastic grainstones of this lithozone were deposited in a middle to upper shoreface environment, where prevalent fair-weather periods resulted in deposition of fine, thick bedded ripple cross laminated beds, punctuated by storm events documented

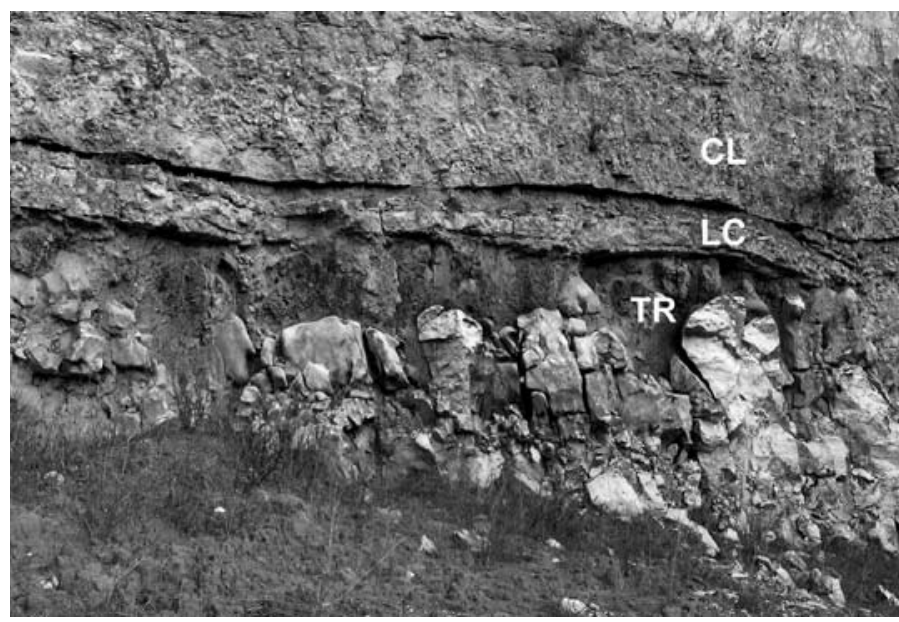

Fig. 6 - The limestone-clay lithozone (LC) at section 8 just above the Terre Rosse (TR). CL: calcarenite lithozone.

- La limestone-clay lithozone (LC) nella sezione 8, al di sopra delle Terre Rosse (TR). CL: calcarenite lithozone.

by coarse, lithoclast-bearing graded beds. Also the fossil assemblages, made up by well-sorted mollusc shell debris, suggest an environment with a considerable hydrodynamic energy.

\section{Megabreccia lithozone}

This lithozone is observable in sections $1,5,6,7,8$ and 9. It rests with an erosional contact on the calcarenite lithozone and consists of a megabreccia single bed with peculiar and quite ubiquitous features (fig. 8):

- erosional base with dm- to m-scale relief; locally, ripped up clasts of the underlying calcarenites are present;

- thickness ranging from 4 to 6 metres;

- a clast-supported and chaotic texture, without any internal partition or graded structure recognizable;

- extremely poor sorting, with angular to poorly rounded clasts ranging from $\mathrm{cm}$-sized pebbles to $\mathrm{m}$-sized boulders and portions of strata;

- diverse nature of the clasts. Some of them are exotic being represented by dm-sized fragments made up of fully lithified wackestones with Middle Eocene planktonic foraminifera (e.g. Turborotalia cerroazulensis, Morozovella lehneri) that have no counterparts in the underlying units. Most clasts, however, consist of lithologies occurring in the local underlying succession: rare $\mathrm{cm}$ sized pebbles made up of Calcare di Bari micritic limestones; $\mathrm{mm}$ - to $\mathrm{cm}$-sized fragments of calcarenites or calcirudites similar to the calcarenite lithozone. The latters commonly show an intense recrystallization and evidence of dissolution and cementation that suggest a meteoric diagenesis. Many clasts, moreover, show abundant bioerosion referable to algae and clionid sponges (fig. 9);

- a poorly cemented matrix composed of the same calcarenites and calcirudites making up the bulk of the clasts. Both planktonic and benthic foraminifera occur in the matrix. Some of them (e.g. Uvigerina auberiana, Paragloborotalia continuosa) are clearly reworked being characteristic of the Miocene, whereas others (e.g. Globorotalia puncticulata), referable to the late Early Pliocene, 


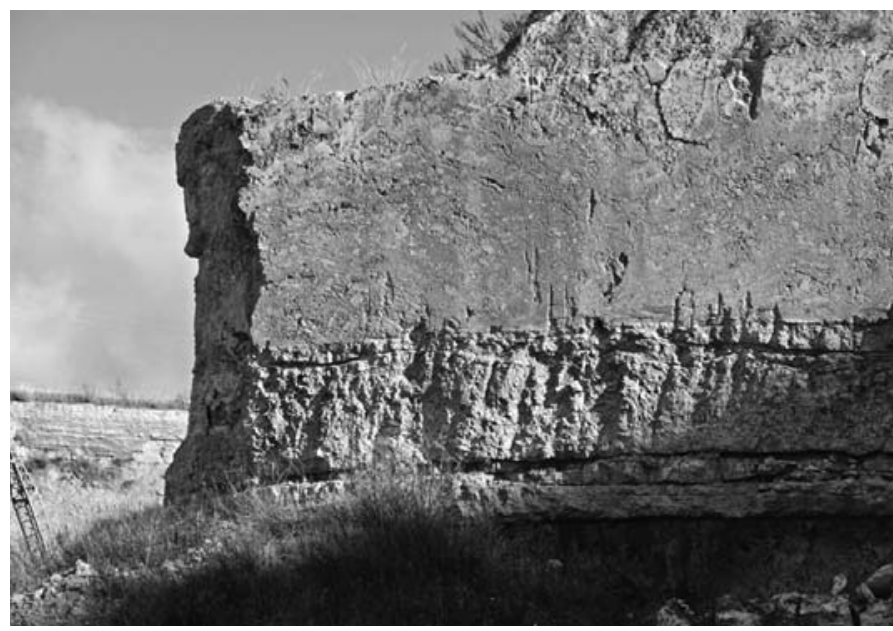

Fig. 8 - The 4 metres-thick megabed of the megabreccia lithozone in the upper part of the quarry wall at section 8 , resting on the calcarenite lithozone.

- Il megastrato potente circa 4 metri della megabreccia lithozone nella porzione superiore della parete di cava dove è esposta la sezione 8 , al di sopra della calcarenite lithozone.

can be considered resedimented and thus nearly coeval with deposition. The degree of cementation is considerably higher in the uppermost part of the megabed, due to the specific diagenetic evolution associated to the unconformity surface at the top (see below);

- occurrence of water escape structures like dm-sized pillars;

- occurrence of soft sediment deformation structures: the metre-sized portions of strata often show gentle to convolute folding, testifying for various degrees of plastic deformation (fig. 10);

- a very sharp upper surface corresponding to the top unconformity, with an abrupt transition to the overlying deposits.

The lack of any internal partition, the considerable thickness, the size of the clasts, the erosional base, the unsorted and chaotic texture and the occurrence of fluid escape structures clearly point to a single en-masse deposition from an hyperconcentrated flow. The Miocene lithologies demonstrate that the provenance of part of the clasts was out of the study area. Bioeroded clasts of intensely recrystallized calcarenites point to reworking in coastal or onshore settings of previously subaerially exposed sediments. The textural and compositional analogy of calcarenite clasts and matrix suggests that both derived from the erosion of semi-lithified sediment: the loose portions made up the matrix, while the partially cemented layers were ripped up and plastically deformed during the flow motion. Regarding the possible causative mechanism, it must be considered that a particularly high-energy process was required to remove and transport unconsolidated sand and gravel, to rip up, deform and transport metre sized boulders and portions of strata, and to scour up to 1 metre down into the sea-bottom sediments.

Considering the sedimentological and palaeogeographic setting, the only reliable phenomenon seems to be a tsunami. Many features of this megabed are reported in the geological literature as identificative criteria for

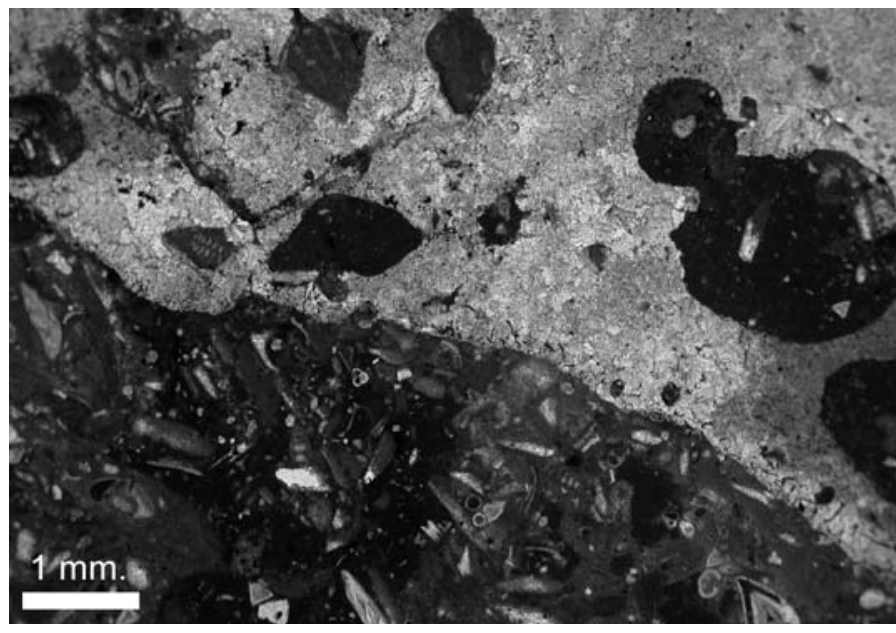

Fig. 9 - Photomicrograph showing the boundary between a recrystallized clast and the matrix within the megabreccia lithozone. Note the microborings and the clionid sponge borings at the edge of the clast. - Microfotografia del limite tra un clasto ricristallizzato e la matrice all'interno della litozona a megabreccia. Si notino le microperforazioni e le perforazioni riferibili a spugne clionidi ai bordi del clasto.

tsunami-related deposits: erosional base, extremely poor sorting, unusual coarse grain size in comparison with the surrounding sediments, mixture of clasts derived from different shallow water and subaerial settings (HARTLEY et alii, 2001; CANTAlamessa \& Di Celma, 2005; Einsele, 1998), intraclasts composed of parts of folded beds, fluid escape structures like dishes and vertical pipes (LE Roux \& VARGaS, 2005; MASSARI \& D’AlessandRO, 2000). Some authors (opp. citt.) suggested that the backflow current of a tsunami is more powerful and erosive than the preceding run-up flow; this is due to the focussing effect of the coastal morphology which tends to channel the backflow, expecially where the flow velocities are increased by rebound phenomena from landward cliffs (MASSARI \& D'AlESSANDRO, 2000). Even if there are no direct measurements of the modern tsunami-related backwash flows and of their effects in the shoreface zone, video footages of the 26 december 2004 Indian Ocean tsunami, which showed great plumes of turbid water moving offshore, confirms the exceptional erosiveness and carrying capacity of the tsunami backwash flows.

In conclusion, it is suggested that during Early Pliocene a tsunami wave passed across the Apricena-Poggio Imperiale area and triggered a strong backwash current that deeply eroded upper shoreface and foreshore sediments, generating a seaward-directed hyperconcentrated debris flow that, after a short distance, quickly froze and deposited its charge. After the megabed deposition probably some reworking took place, as can be inferred from the erosional nature of the unconformity surface at the top and from the lack of a graded bed top which on the contrary has been reported for other tsunami-related deposits (EINSELE, 1998).

\section{Isognomon biostromal lithozone}

This unit has been observed only in sections 1 and 5 where it crops out with homogeneous bio- and lithofacies in a single, massive bed 0,80 to $1,60 \mathrm{~m}$ in thickness. It lies on the unconformity surface corresponding to the 


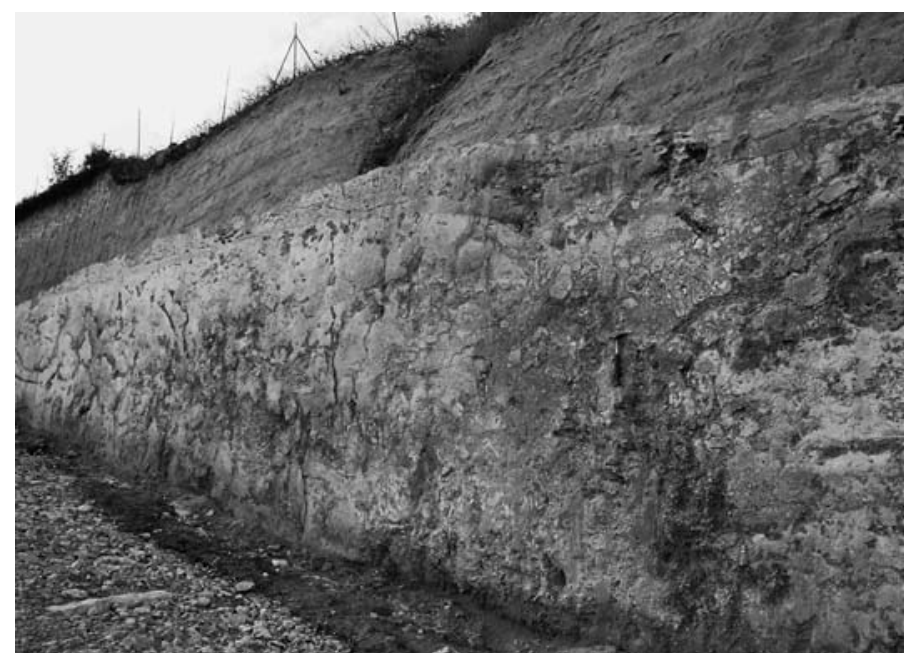

Fig. 10 - The megabreccia lithozone in the westernmost sector of section 7. Note the poorly-sorted and chaotic texture of the megabed, and the occurrence of folded metre-sized portions of strata. Hammer for scale.

- La megabreccia lithozone nel settore occidentale della sezione 7. Si noti la tessitura caotica e poco classata del megastrato, e la presenza di porzioni metriche di strati piegati. Un martello come scala.

megabreccia lithozone top (fig. 11) and is closed by an undulated hard ground surface with Lithophaga borings. The structure is biostromal and derives from the accumulation of scaly shells of the large pelecipod Isognomon (Hippochaeta) maxillatus in a whitish to pinkish packstone matrix. The latter is a packstone with mm-sized micritic intraclasts, pelecypod fragments, benthic foraminifera (Elphidium sp.), echinoids fragments and spines; firm-ground burrows are commonly observable. The big pelecypod shells are most frequently univalve and intensely bored; complementary fossils are scattered pectinids and rare gastropods preserved as internal molds. The assemblage represents a palaeocommunity with demic elements. The $I$. maxillatus population developed

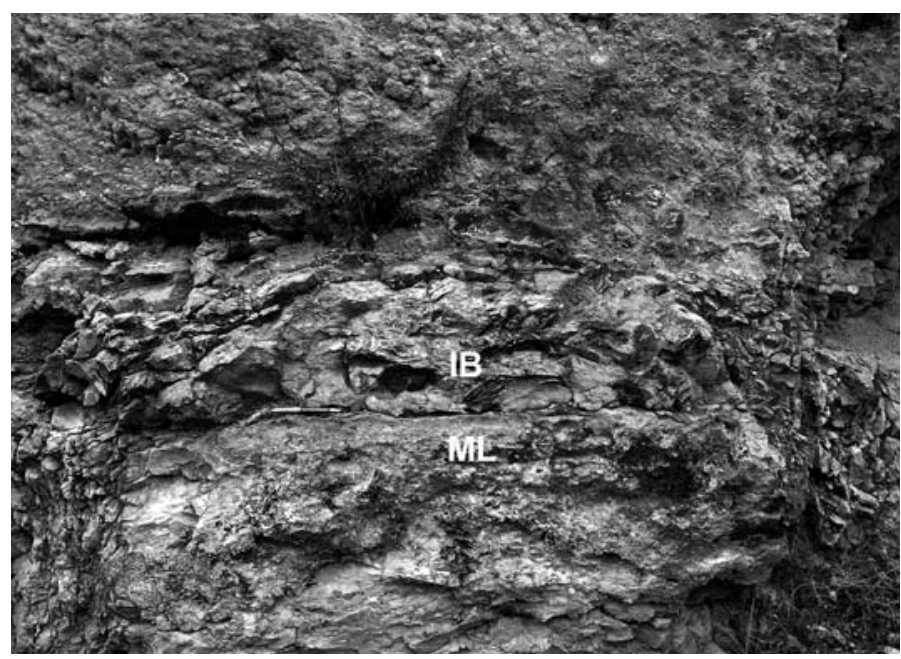

Fig. 11 - Planar unconformity surface at the basal boundary of the Isognomon biostromal lithozone (IB) at section 1, overlying the megabreccia lithozone (ML).

- Superficie planare di discontinuità alla base della Isognomon biostromal lithozone (IB) nella sezione 1, a tetto della megabreccia lithozone $(M L)$.

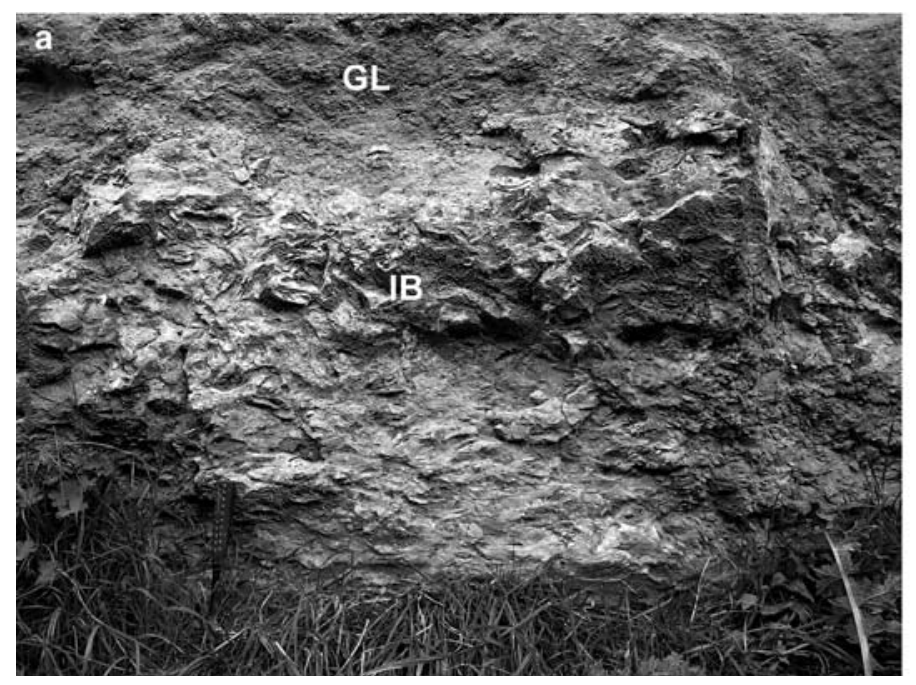

gradually: at the base the bed is matrix-supported and pelecypod shells are medium-sized and sub-horizontal; at the top the texture is shell-supported and fossils are large, both univalve and bivalve, randomly oriented. The biostrome is dome-shaped, due to biological constraints in a sort of patch reef structure; the original geometry is locally hidden by the upper unconformity that cuts through it (fig. 12).

Isognomon specimens have been reported by ABBAzzI et alii (1996) within their facies 3c, corresponding to «pinkish limestones» of VALLERI (1984), together with other fossils, such as corals, Chlamys pesfelis, barnacles, that in our sampling were found in different overlying units that will be described below.

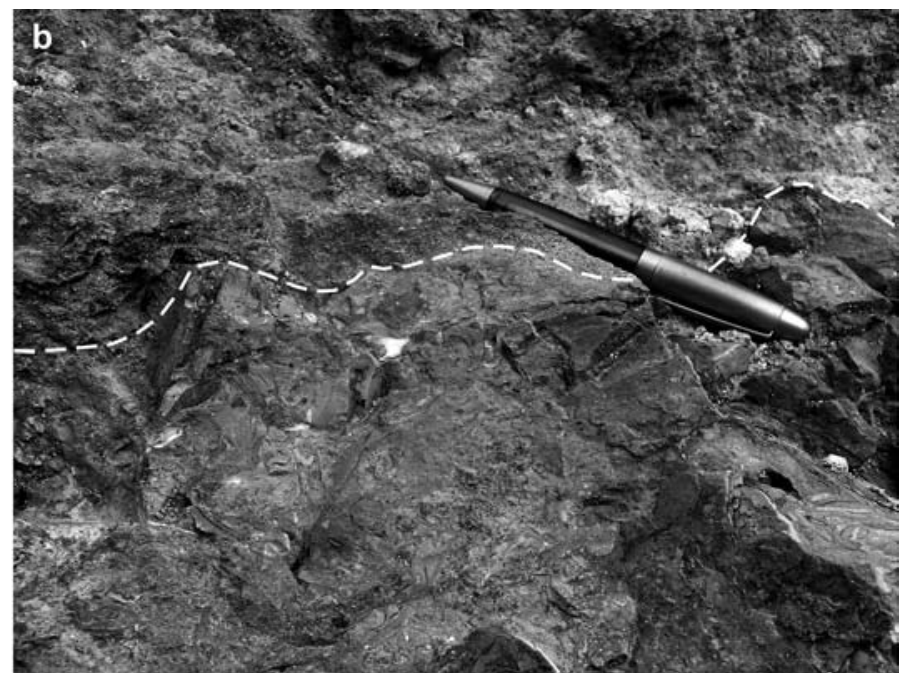

Fig. 12 - The Isognomon biostromal lithozone (IB) at section 1: (a) Dome-shaped architectures at the topmost lithozone. GL: Glycymeris bearing lithozone; (b) Erosional surface (broken line) cutting I. maxillatus shells and bioclasts at the uppermost unconformity surface.

- La Isognomon biostromal lithozone (IB) nella sezione 1: (a) Geometrie a duomo a tetto della litozona. GL: Glycymeris-bearing lithozone; (b) Superficie erosionale (linea tratteggiata) che taglia i bioclasti e le valve di I. maxillatus in corrispondenza della discontinuità sommitale. 
The environmental meaning of such a biostromal unit derives from the autoecological characters of Isognomon (Hippochaeta) maxillatus, which is a marine soft-bottom dweller with semi-infaunal habitus on unconsolidated medium-energetic bottom in the proximal part of the infralittoral zone, possibly influenced by tidal currents (SAVAzZI, 1995; FERRERo \& PAVIA, 1996). As to chronostratigraphic value, I. maxillatus is reported from the Miocene to the lower part of the Pliocene, earliest Piacenzian (MONEGATTI \& RAFFI, 2001).

\section{Barnacle-coral biostromal lithozone}

It consists of rudstones with a shell-supported texture; palaeobiological elements are represented by large, mainly coalescent and mostly entire carapaces of Balanus sp., and by solitary, ahermatipic corals such as $B a-$ lanophyllia, Caryophyllia, Flabellum, bryozoans, pelecypods (veneroids), gastropods (e.g. Bolma rugosa) and undeterminable benthic and planktonic foraminifera. Scleractinia and Mollusca taxa with original aragonite skeletons are preserved as internal molds, whereas barnacles preserve the original calcitic carapace. Fossils do not show any sorting, being represented by specimens ranging from few $\mathrm{mm}$ to more than $10 \mathrm{~cm}$ for barnacles; geopetal structures coherent with bedding indicate the absence of taphonomic reworking (fig. 13). Fossils lie both in growth position (e.g. barnacle colonial group: fig. 14), or differently displaced to overturned; though the latter must be classified as resedimented elements according to terminology proposed by FERNANDEZ-LOPEZ (1991), all fossils represent demic components of the original palaeocommunity. As to palaeoenvironmental definition, the coral families Cariophylliidae, Dendrophyllidae (Balanophyllia ap.) and Flabellidae are referred to relatively deep bottoms, below the infralittoral/circalittoral transition (cf. CHAIX et alii, 1999). ABBAzzI et alii (1996) refer barnacles to Balanus (Megabalanus) tintinnabulum that, according to SWIERCZEWSKA-GLADYSZ (1994; see also KAMP, 1988), is an "extremely shallow water» taxon. This however is inconsistent with the observed coral community. Further analyses, out of the scope of the present work, are needed to solve the taxonomic question.

This unit corresponds to the "calcari variegati» described by D'ALESSANDRO et alii (1979, p. 13, 16); similar barnacle biofacies were also recorded from Cagnano Varano (op. cit., p. 14). On the other hand, this lithozone partly fits with the subunit 3c of ABBAzzI et alii (1996) in which, however, biofacies pertaining to different units topologically under- and overlying are included.

Thickness and development of the barnacle-coral biostromal lithozone vary a lot across the study area: in the western sector (section 9) it occurs as thin (dm-thick) and lenticular bodies; moving eastward, continuity and thickness of the biostrome progressively increase (sections 6,7 ) and in the easternmost sector (section 2) it is several metres thick and characterized by a tabular geometry with massive beds. These changes were likely controlled by palaeoenvironmental constraints, such as penetration of light and current activity in turn related to depth. It could be concluded that on shallow bottoms larger filter- and suspension-feeder communities (corals, bryozoans, barnacles) thrived and gave rise to thick, continuous biostromes whereas in deeper settings only limited patches could develop.

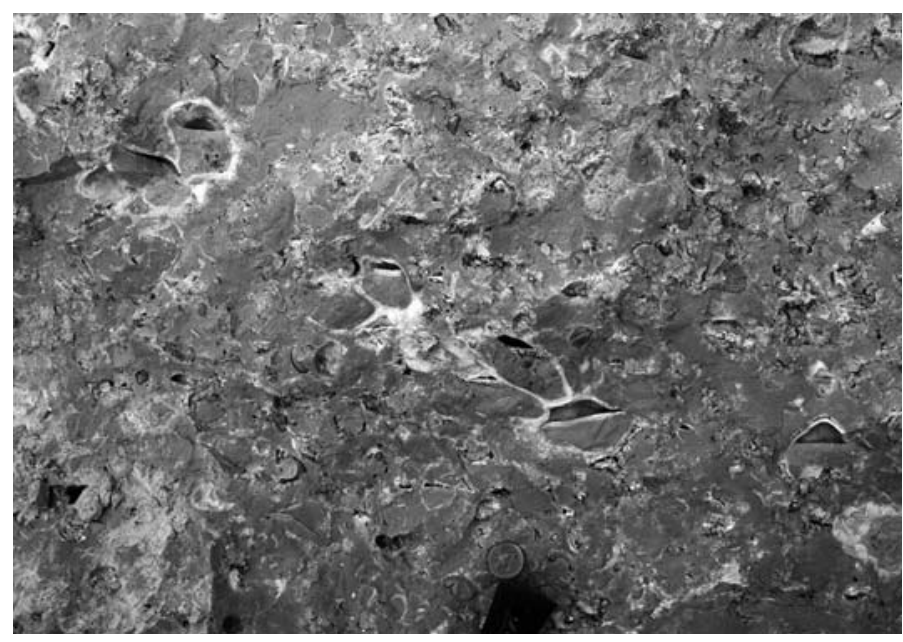

Fig. 13 - The barnacle-coral biostromal lithozone at section 2. Note the congruent geopete structures in autochthonous carapaces of Balanus sp., associated with coral internal molds. A one euro coin for scale.

- La barnacle-coral biostromal lithozone nella sezione 2. Si notino le strutture geopete nei carapaci autoctoni di Balanus sp., associati a modelli interni di coralli. Una moneta da un euro come scala.

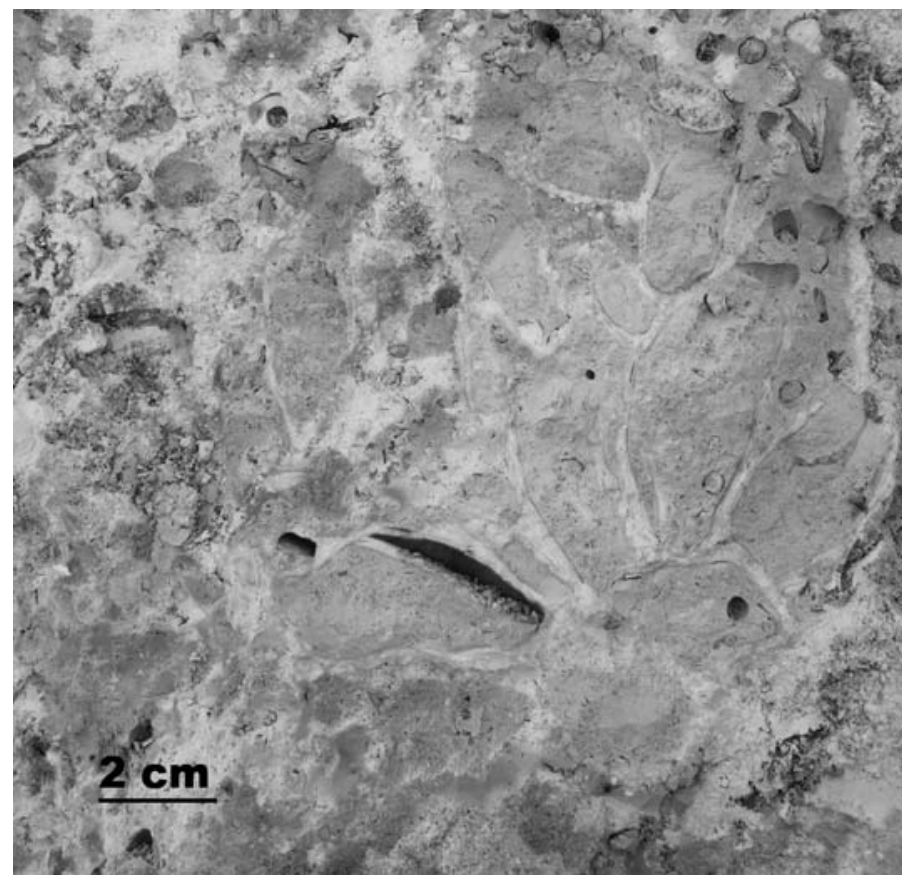

Fig. 14 - Cluster of gregarious barnacles in growth position from the barnacle-coral biostromal lithozone at section 2 .

- Cluster di balanidi gregari in posizione di crescita nella barnaclecoral biostromal lithozone della sezione 2.

\section{Barnacle-coral biostromal breccia lithozone}

It consists of a matrix-supported breccia with $\mathrm{mm}$ - to $\mathrm{cm}$-sized clasts made up of a packstone with fragments of barnacles, corals and echinoderms, plus some undeterminable benthic and planktonic foraminifera; the matrix is a whitish wackestone with barnacle and coral fragments. This calcareous body was described by VALLERI 


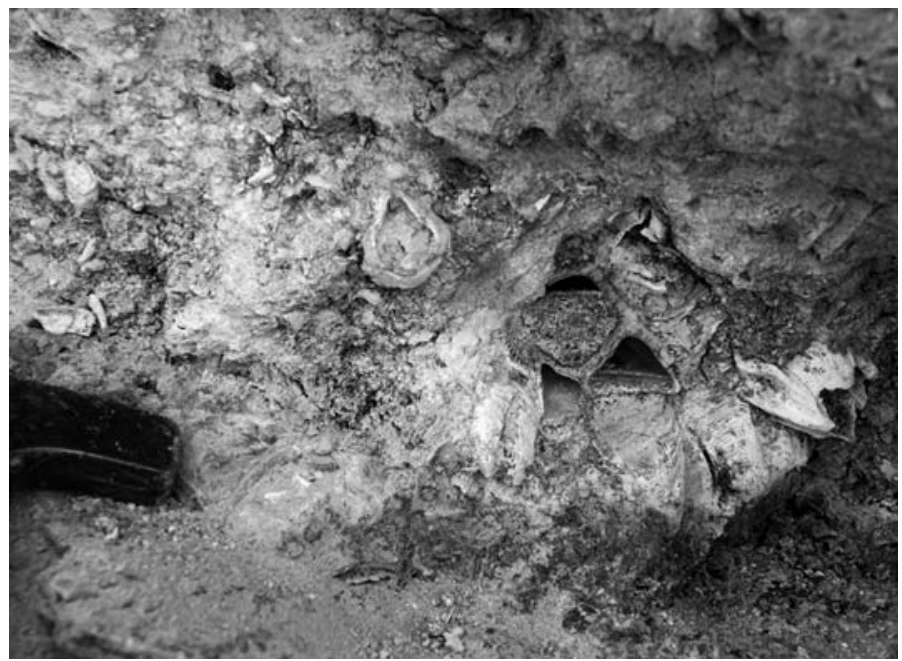

Fig. 15 - In section 7 the barnacle horizon is composed of a 10-15 cm thick shell-supported layer just overlying a massive bed of the barnacle-coral biostromal lithozone.

- Nella sezione 7 il barnacle horizon è costituito da un sottile $(10-15 \mathrm{~cm})$ livello sovrapposto alla barnacle-coral biostromal lithozone.

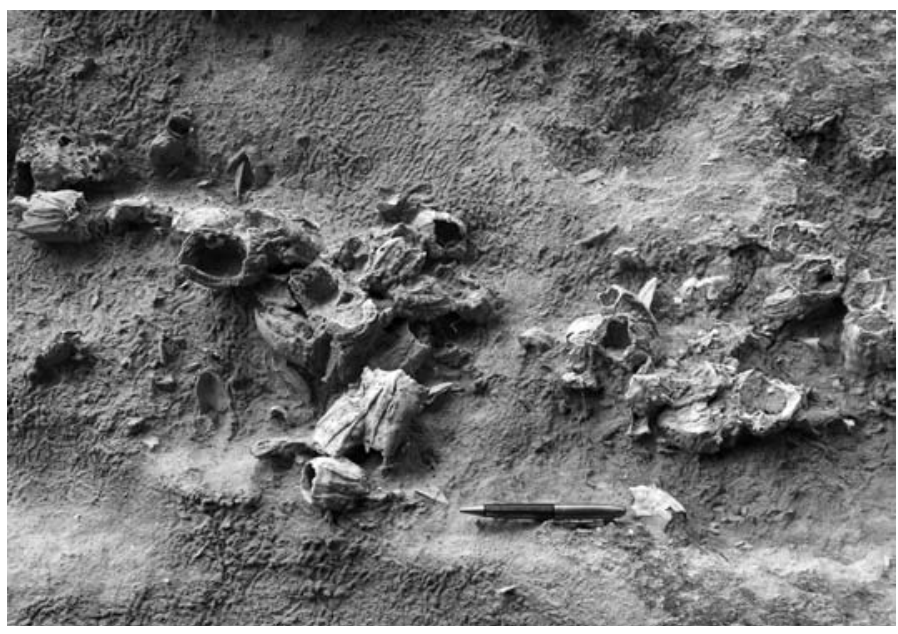

Fig. 17 - Close-up of fig. 16, showing resedimented carapace clusters of gregarious Balanus sp. in the barnacle-bearing lithozone at section 1.

- Dettaglio della fig. 16: insiemi risedimentati di carapaci di Balanus sp. nella barnacle-bearing lithozone nella sezione 1.

(1984) as «pinkish limestone»; the presence of planktonic foraminifera in its matrix (Globorotalia puncticulata, G.p. padana and $G$. bononiensis) biostratigraphically refers deposition to the very late Early Pliocene. This breccia likely resulted from gravitational reworking of barnaclecoral-bearing semi-lithified sediments along steep slopes.

\section{Barnacle horizon}

It is represented by a single bed, ranging in thickness from 20 to $40 \mathrm{~cm}$, resting above the barnacle-coral biostromal lithozone. It is composed by coalescent and laterally growing barnacle carapaces of Balanus sp. and very scattered corals. In most cases, fossils are dimensionally selected (carapaces $6-10 \mathrm{~cm}$ high) and show con-

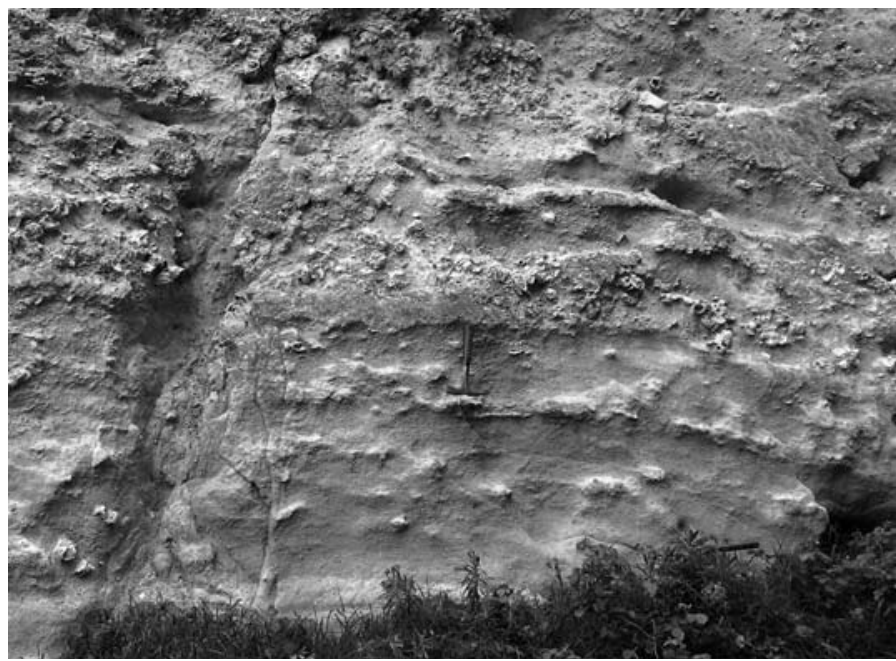

OFig. 16 - The barnacle-bearing lithozone at section 1 is composed of greenish bioclastic packstones with clustered or solitary barnacle caparaces lined up in ill-defined horizons.

- La barnacle-bearing lithozone della sezione 1 è composta da calcareniti bioclastiche verdastre che contengono carapaci di balanidi, solitari o gregari, deposti secondo orizzonti discontinui.

gruent geopetal infillings; they are preserved in life position or little displaced and laying down, i.e. they are demic and the palaeopopulation represents a residual, size-selected barnacle community (fig. 15). The thickness of this horizon is greater (up to $40 \mathrm{~cm}$ ) approaching the southern border the Apricena horst (section 3). The scarcity of circalittoral corals and the homogeneous large size of barnacles point to an increase in hydrodynamic energy compared to that inferred for the underlying barnacle-coral biostrome. This horizon is present in sections $3,4,6,7$. It does not correspond to any biofacies described in the regional literature (e.g. VALLERI, 1984; ABBAzzI et alii, 1996); nevertheless, it assumes great significance as a likely source of fossils and sediment for the next lithozone.

\section{Barnacle-bearing lithozone}

It consists of a greenish bioclastic packstone with large, cm-sized, barnacle carapaces. It shows a wedgeshaped geometry, with an abrupt pinch out termination against a sharp, subvertical surface cut into the Calcare di Bari Fm., and concave-up bedding surfaces. Beds show a thickening and coarsening-upward trend defined by the abundance of large barnacles: at the base, barnacles, occurring as solitary specimens or in clusters, make up thin and discontinuous horizons, whereas in the upper part they are more abundant and give rise to massive shell-supported layers (fig. 16). All fossils are resedimented: single or clustered carapaces, and free plates are normally separated and broken and entire specimens are commonly overturned (fig. 17).

In addition to barnacles, many other fossils have been recognized with significant changes between the lower and upper parts. In the lower part, bryozoans, echinoid spines, pelecypods (Chlamys sp.), corals, coralline algae fragments, and scattered foraminifers are present. A minor siliciclastic fraction (qtz. 5\%) also occurs. In the upper part the assemblage is composed of specimens of both vagile and sessile biota: among the former, common 
ophiuroid ossicles, decapod crustaceans, rare gastropods; among the latter, Cheilostomata bryozoans, serpulids, frequent brachiopods (Megerlia truncata, juvenile Terebratulina retusa). Both assemblages indicate deposition on circalittoral bottoms that can be easily compared to those of the Coastal Detritic (namely the "Ophiura texturata" facies) and partly of the "Coralligenous» biocoenoses described by PÉRES \& PICARD (1964) on the modern Mediterranean platform. In fact, among brachiopods, $T$. retusa is abundant below $-90 \mathrm{~m} ; M$. truncata favours the coralligenous bottoms and is more frequent in the 100-150 depth range.

In the lower part of section 1 a rich planktonic foraminifera assemblage was recognized. It is characterised by the occurrence of Globigerina bulloides, Globigerinella siphonifera, Globigerinoides ruber, Globorotalia puncticulata, Neogloboquadrina dutertrei, Orbulina universa, that fits exactly with Valleri's record (1984) from the same outcrop. The benthic microfossil assemblage is well diversified and characterised by a large number of foraminifers and ostracods (see Appendix-1). As to biostratigraphy, G. puncticulata allows the assemblage to be referred to the subzone MPl4b of SPROVIERI (1992), i.e. to the late Zanclean. The ostracod assemblage is mainly composed of species which are frequent on the circalittoral bottoms or the modern Mediterranean Sea (BONADUCE et alii, 1975; BREMAN, 1976); this palaeoenvironmental reference is supported also by the relative frequency of some benthic foraminifera such as Cibicidoides pachyderma, Gyroidina neosoldanii, Melonis barleeanum (JoRISSEN, 1987; SGARRELLA \& MONCHARMONZEI, 1993). The abundance of barnacle carapaces and the morphological analogy allow to suggest that this lithozone derives from reworking of skeletal remains of the barnacle horizon.

This lithozone is equivalent of the subunit $3 \mathrm{~b}$ of ABBAzZI et alii (1996) and to the "greenish clays» of VALLERI (1984) described in the Cava Dell'Erba section, which corresponds to our section 1 .

\section{Glycymeris-bearing lithozone}

This unit has been observed only in section 1 where it crops out with homogeneous bio- and lithofacies in a set of thin to medium beds with a maximum thickness of $4 \mathrm{~m}$. Usually it overlies the Isognomon biostrome, but locally it rests directly on the unconformity surface at the megabreccia lithozone top. At the entrance of the artificial trench, which was dug to enter the quarries, this carbonate lithozone is completely cut off by the unconformity surface that marks the base of the overlying formation; in the opposite direction the thickness of the Glycymerisbearing lithozone progressively increases, showing local sudden variations due to the presence of small normal faults that displaced the underlying Isognomon biostrome, increasing the accommodation space (fig. 18).

The lithofacies was described by ABBAZZI et alii (1996) as a whitish to light ochre calcarenites with calcisiltitic matrix. The biofacies is constituted by bivalve and univalve shells of the pelecypod Glycymeris insubrica, which are packed together and give a pseudo-nodular aspect to the calcarenite (fig. 19). Other macrofossils are represented by pectinids and gastropod molds (e.g. Schilderia utriculata, pteropod Clioinae), sparse brachiopods and rare individual corals; bryozoans are common, both Tubu-

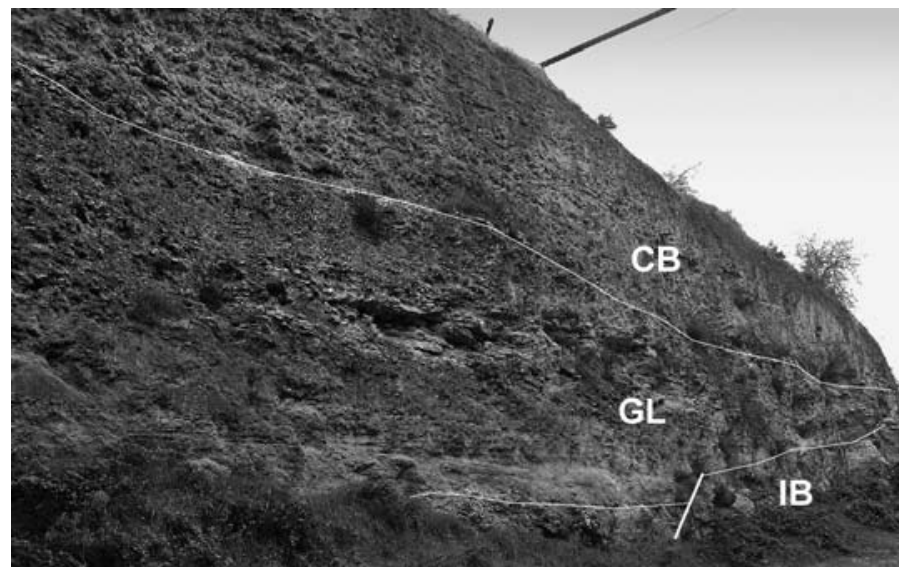

Fig. 18 - The Glycymeris-bearing lithozone (GL) cropping out in the central part of section 1 . Note the thickness variation due to small normal faults affecting the underlying Isognomon biostromal lithozone (IB), that increases the accommodation spaces for deposition of the calcarenites with $G$. insubrica palaeocommunities. CB: Calcari a Briozoi Fm.

- La Glycymeris-bearing lithozone (GL) affiorante nella parte centrale della sezione 1. Si notino le variazioni di spessore legate alla presenza di piccole faglie normali che hanno dislocato la sommità della sottostante Isognomon biostromal lithozone (IB) e aumentato lo spazio disponibile per la deposizione delle paleocomunità a G. insubrica. CB: Calcari a Briozoi Fm.

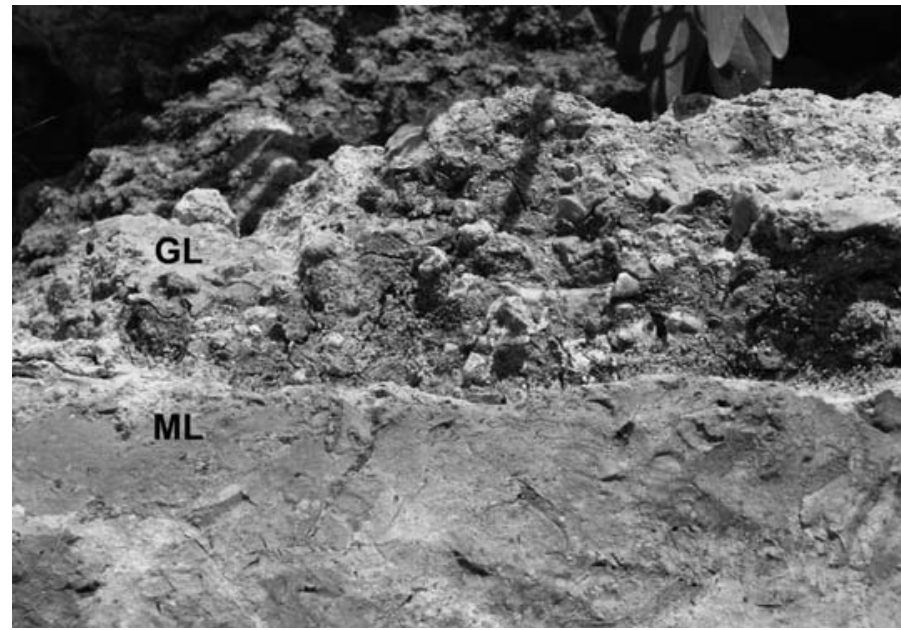

Fig. 19 - Locally, in section 1, the Glycymeris-bearing lithozone (GL) lies directly on the unconformity surface of the topmost megabreccia lithozone (ML). Note the numerous boring traces affecting the boundary surface.

- In tratti della sezione 1, la Glycymeris-bearing lithozone (GL) poggia direttamente sulla discontinuità a tetto della megabreccia lithozone $(M L)$. Si notino le numerose gallerie di organismi litofagi sotto la superficie di discontinuità.

liporata and Cheilostomata, and represented by encrusting multilaminar, encrusting rigid robust to delicate branchings, and radiate forms too. It is difficult to better characterize the whole fossil assemblage because of the complete dissolution of aragonitic skeletons; in any case, it does not correspond to the list recorded by ABBAzzI et alii (1996) in their facies 5, who mixed fossils coming from the overlying Calcari a Briozoi Fm. too. Similar Glycymeris insubrica palaeocommunities are known from different Neo- 


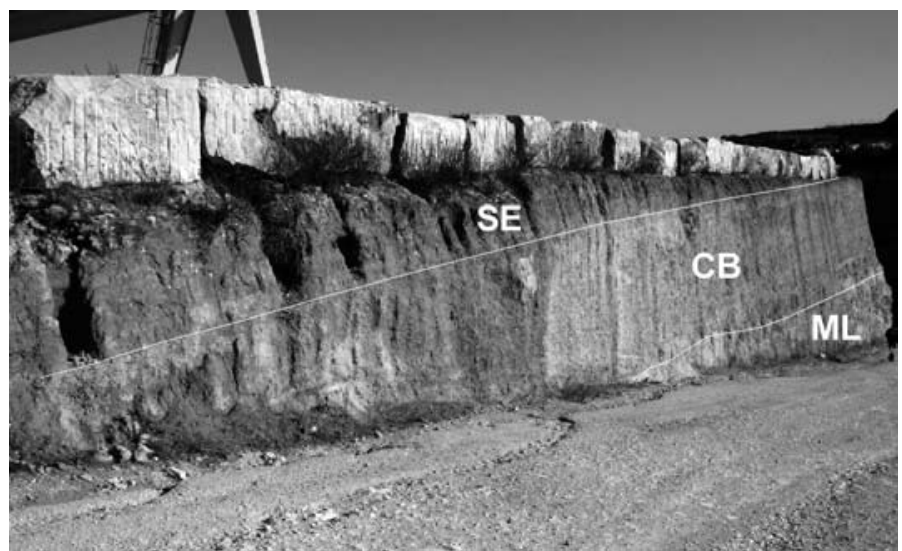

Fig. 20 - The 6-metres thick yellowish lumpy calcarenites of the Calcari a Briozoi Fm. (CB) at section 7. ML: megabreccia lithozone. SE: Serracapriola Fm. C. Bertok for scale.

- Le calcareniti giallastre della Formazione dei Calcari a Briozoi (CB) nella sezione 7 con aspetto pseudonodulare e circa 6 metri di spessore. ML: megabreccia lithozone. SE: Serracapriola Fm. C. Bertok come scala.

gene to Recent places and characterize distal infralittoral bottoms, like those described from the northern Italy Pliocene (FERRERO \& PAVIA, 1996) or comprised in the "Fine Well Sorted Sands" biocenosis of the modern Mediterranean Sea (PÉRES \& PICARD, 1964).

Bryozoan assemblages confirm the reference to a middle-high energetic bottom at the infralittoral/circalittoral transition, according to the morpho-structural scheme proposed by NELSON et alii (1988). No biostratigraphic data are available; however, an age older than the barnacle-coral biostromal breccia lithozone (latest Early Pliocene) can be inferred by geometric relationships (see below).

\section{CALCARI A BRIOZOI FORMATION}

It consists of medium to coarse bioclastic calcarenites, poorly cemented and organized in ill-defined dm- to metre-thick beds; the colour is yellowish and the appearance is lumpy because of localized cementation and the presence of algal nodules. The formation is thinner in the central horst sector of the study area; on the contrary, it can reach thickness of several tens of metres on the downthrown blocks of the two main synsedimentary normal faults. Moving westward, the Calcari a Briozoi Fm. progressively reduces its thickness and finally pinches out, as it is well exposed in the western sector of section 8. Further to the west (section 9), however, this formation locally occurs as limited, dm-thick patches of sediment infilling depressions at the top surface of the megabreccia lithozone. These sediments are made up of packstones with a large amount of gastropods and other bioclasts (bivalves, corals, echinoderm fragments, benthic foraminifera, miliolids). Gastropods are well preserved because of shell recrystallization (see Appendix-4). The assemblage reflects deposition on silty bottoms of the proximal circalittoral zone, equivalent to the Mediterranean Coastal Terrigeneous Mud (PERES \& PICARD, 1964).

Fossils are common throughout the whole Calcari a Briozoi Fm., with some differences in assemblages from place to place. Actually, the palaeontological richness was already demonstrated by ABBAzZI et alii (1996); neverthe- less, they mixed the fossil record of different units and facies $(3 b, 3 c, 5,6)$ so that the real taxonomic content cannot be defined precisely. In the following paragraphs the main tracts of the fossil assemblages are detailed; the exhaustive study is out of the scope of this paper and could be completed only by an intensive field work.

The best exposure of the Calcari a Briozoi Fm. is in the eastern side of section 7 , along the entrance road of the quarry (fig. 20) where the yellowish calcarenites reach $6 \mathrm{~m}$ of thickness. The lower boundary is erosional on the underlying lithozones and the basal layer incorporates $\mathrm{cm}$ - to dm-sized pebbles. The fossil assemblages is dominated by colonial Cheilostomata and subordinately Tubuliporata bryozoans; the latter are arranged as erect colonies or thick and large laminar structures which are in turn encrusted by other bryozoans and serpulids; corallinae algae are common both as encrusting structures and pluricentimetric spheroids. Fossil shells belong to brachiopods (Megathiris detruncata, Terebratulina retusa), pelecypods (Chlamys multistriata, $C$. opercularis), gastropod molds (Astraea rugosa); crushed echinoid skeletons are also present (Schizechinus sp., Spatangus cf. purpureus, Echinocyamus pusillus).

The basal contact of the yellowish calcarenites is easily observable also in section 3 , on both sides of the abandoned entrance to Gaetano Dell'Erba's quarry. The calcarenites, cropping out for about 5 metres of stratigraphic thickness, rest on the barnacle-coral biostromal lithozone through an erosional surface. Calcarenites are well sorted and medium-sized, being characterized by a non-homogeneous cementation. They contain coralline algae sferoids, bryozoan colonies, and many bioclasts deriving from different invertebrate groups such as echinoid spines, barnacles, crustaceans, serpulids. Entire macrofossils are abundant with brachiopods, pelecypods and gastropods (see Appendix-2a). The brachiopod assemblage indicates deposition on circalittoral bottoms at a depth that could reach $-100 \mathrm{~m}$; the depositional environment approximates the "Coastal Detritic» biocenosis of the modern Mediterranean platform (PÉRES \& PICARD, 1964) due also to the large amount of bryozoans that created a semi-rigid bottom suitable for sessile and semi-sessile biota and for vagile patelliform gastropods. Similar brachiopod assemblages on detritic bottoms are known from other regional contexts (PAVIA \& ZUNINO, 2008) that are equally referred to the Mediterranean "Coastal Detritic» biocenosis. This palaeoenvironmental reference is also supported by the structural morphologies of the bryozoans with dominant erected rigid, delicate and robust branchings associated to encrusting multilaminar A and C Cheilostomata and fenestrate Tubuliporata; these forms point to hard bottoms in a middle to outer platform environment (NELSON et alii, 1988).

Microfossils of the lower layers of the bryozoan calcarenites were sampled in section 1. The planktonic record is limited to Globigerina bulloides, Globigerinoides trilobus, Globorotalia inflata and Orbulina universa, together with the rare specimens of $G$. aemiliana listed by VALLERI (1984). On the contrary, benthic assemblages are rich of foraminifers (see Appendix-2). The palaeoenvironmental meaning is specified by the commonest taxa. Cibicides lobatulus, mostly reported from infralittoral vegetated bottoms (LANGER, 1988), is also present in the Mediterranean circalittoral detritic bottoms (SGARRELLA \& MoncharmonT, 1993). In the Adriatic Sea, Neoconor- 
bina terquemi is reported form sandy bottoms 30-60 m deep (JORISSEN, 1987); high percentages of this species have also been recorded in coralligenous detritic bottoms of the Gulf of Policastro (SGARRELla et alii, 1985). On the whole the assemblages of this lower part of the bryozoan calcarenites can be related to a detritic bottom of the proximal circalittoral. As to biostratigraphy, $G$. inflata allows the assemblage to be referred to the subzone MP16 of SPROVIERI (1992) corresponding to the Gelasian Stage; moreover, the base of this formation can not be older than the Gelasian Stage due to the presence of Joania cordata which is known to be distributed from Late Pliocene to Recent.

The top of the Calcari a Briozoi Fm. is easily observable in sections 2 and 7 and corresponds to an erosional unconformity surface marked by a hard, decimetre-thick layer mainly resulting from the lateral coalescence of encrusting coralline algae colonies (figs. 21, 22). In section 2, within this hardened layer, rounded, encrusted and bored pebbles of different lithologies (Calcare di Bari limestones, barnacle-coral biostromal limestones, various kinds of calcarenites) occur and document intense current activity and a prolonged interruption of sediment accumulation. Just below the hardened layer, macrofossils are represented by univalve pectinids and big patellid gastropods (Patella ferruginea) whose highconical shell reflects an elevate energetic environment. The benthic microfossil assemblages are composed of foraminifers and ostracods that are referable to an inner infralittoral bottom (see Appendix-3); more in detail, the depositional bottom of the topmost Calcari a Briozoi Fm. fossil assemblages is referable to one of the shallow communities described by PÉRES \& PICARD (1964) among the mediolittoral «Hard Bottoms» biocenoses of the Mediterranean Sea.

The Calcari a Briozoi Fm. is well exposed in sections $1,2,3,6,7$. It corresponds to the "yellow calcareous sands» and to the unit 6 respectively of VALLERI (1984) and ABBAZzi et alii (1996).

\section{SERRACAPRIOLA FORMATION}

It crops out with typical features in sections $7,8,9$ (fig. 23). It occurs also in section 2 , even if with a slightly different facies. The thickest succession is at section 9 which is the same figured by CAPUANO et alii (1996). It can be subdivided in two parts: the lower one is made up of about 10 metres of silty sands with planar lamination; in the upper part, about $30 \mathrm{~m}$ thick, siliciclastic sands show large scale cross-bedding structures (fig. 24) that indicate a fan-delta environment and a clastic influx supplied by a NW source after the drowning of Fortore High (CAPUANo et alii, 1996; RobUSTElli \& AUCELli, 2001).

Macrofossils are present only at the very base of section 9 where a cluster assemblage of the well-known circalittoral Terebratula scillae has been detected. Microfossil assemblages from the lower part are similar in sections 8 and 9. Planktonic foraminifers are represented by Globigerina bulloides, Globigerinoides trilobus, G. ruber, Globorotalia inflata, G. scitula, Neogloboquadrina dutertrei, left coiled specimens of Neogloboquadrina pachyderma, Orbulina universa; rare Globorotalia puncticulata and $G$. bononiensis-inflata intergrading were found in section 8. Benthic assemblages are rich of foraminifers and ostracods (see Appendix-5 and Appendix-6). The

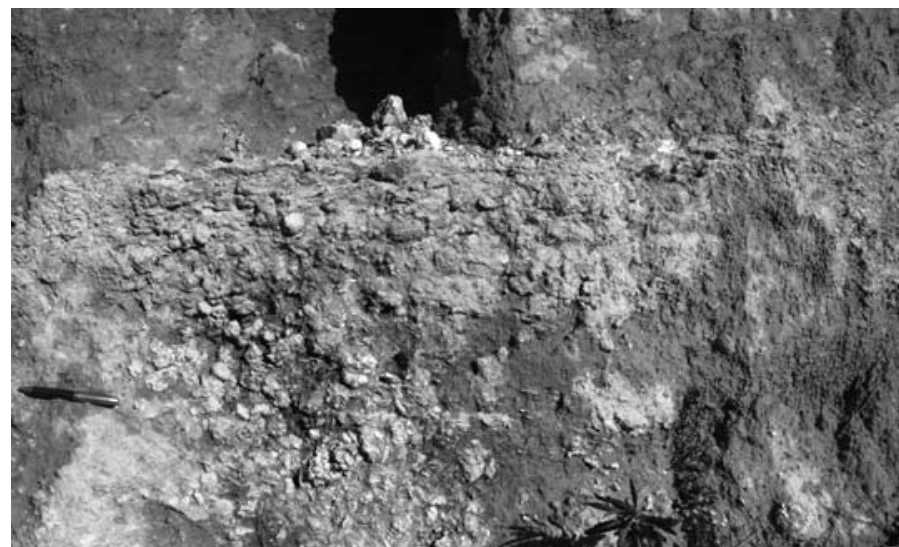

Fig. 21 - The Calcari a Briozoi Fm. at section 7, closed by a $30 \mathrm{~cm}-$ thick layer hardened by coalescent structures (nodules and crusts) of coralline algae.

- I Calcari a Briozoi nella sezione 7 sono chiusi a tetto da un livello indurito spesso $30 \mathrm{~cm}$., cementato da strutture coalescenti (noduli e croste) di alghe corallinacee.

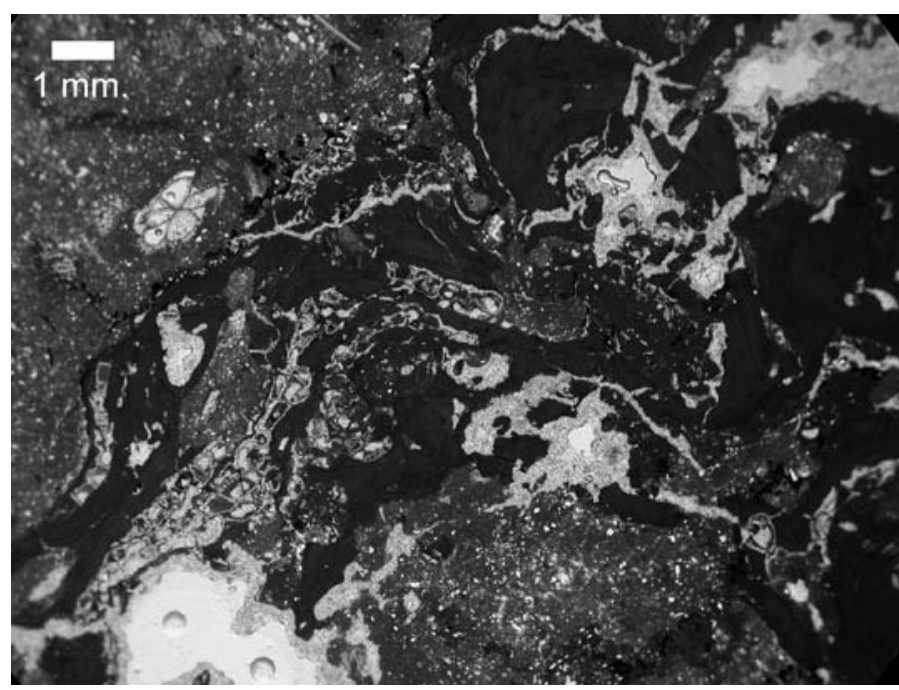

Fig. 22 - Photomicrograph showing bryozoans and encrusting coral line algae within the hard layer of the topmost Calcari a Briozoi Fm. The algae talli are crossed by fractures, partially enlarged by dissolution and filled with a fine-grained crystalline cement spar.

- Microfotografia dei briozoi e delle alghe corallinacee incrostanti all'interno del livello indurito al tetto dei Calcari a Briozoi. Le alghe sono attraversate da fratture parzialmente allargate da processi di dissoluzione e riempite da un cemento calcitico a grana fine.

foraminifer fraction is constituted by both infralittoral species and taxa commonly occurring, in the Mediterranean Sea, from circalittoral to deeper environments, such as Cassidulina carinata, Cibicidoides pachyderma, Globocassidulina subglobosa (SGARRELLA \& MONCHARMONT-ZEI, 1993; MORIGI et alii, 2005). The assemblages can thus be interpreted as the result of a slight downward transport of shallower species at the infralittoralcircalittoral transition. As to chronostratigraphy, the occurrence of Globorotalia inflata indicates an age not older than the Gelasian; more precise information derives from some ostracods (e.g. Aurila punctata, Echinocythereis postulata, Loxoconcha turbida) which 


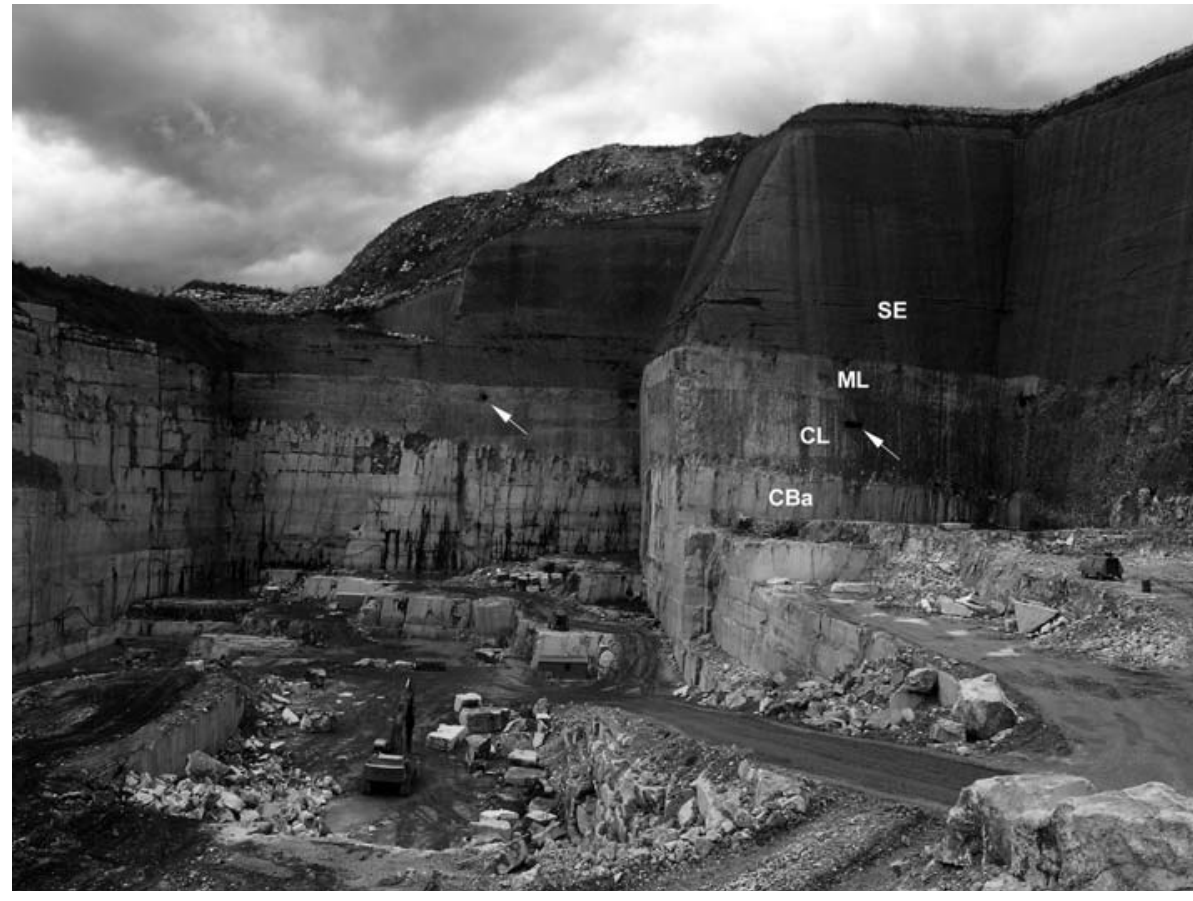

Fig. 23 - General view of section 9 which is composed of the Mesozoic Calcare di Bari Fm. (CBa), the Lago di Varano Fm. with the calcarenite (CL) and the megabreccia (ML) lithozones, and finally of the siliciclastic Serracapriola Fm (SE). Note the presence of karstic tunnels inside the Varano carbonates (arrows). - Vista generale della sezione 9, composta in successione da: Fm. di Calcare di Bari (CBa), Fm. del Lago di Varano con la calcarenite lithozone (CL) e la megabreccia lithozone (ML); alla sommità della sezione, arenarie silicoclastiche della Fm. di Serracapriola (SE). Si noti la presenza di condotti carsici nei carbonati della Fm. del Lago di Varano (frecce).

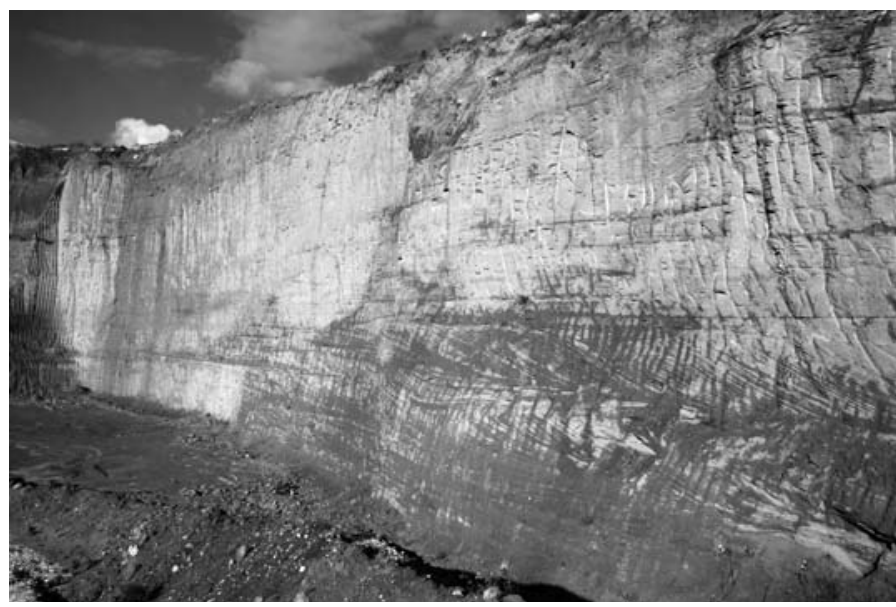

Fig. 24 - The upper portion of the Serracapriola Fm. at the section 9. Note the large-scale cross-bedding stratification.

- La porzione superiore della Fm. di Serracapriola nella sezione 9. Si noti la stratificazione incrociata a grande scala.

point to an Early Pleistocene age, as also suggested by the presence of left coiled specimens of $N$. pachyderma and by the brachiopod $T$. scillae. The rare Globorotalia indicating Early to Middle Pliocene document reworking within the assemblages. Actually, such biostratigraphic data fit with the Early Pleistocene age already referred by Robustelli \& AucElli (2001) for Serracapriola Fm. in the western sector of the Apricena horst.

Section 2 was opened in 2008 along a new entrance way to Gaetano Dell'Erba's quarry. It shows peculiar facies and stratigraphy and, because of this, has been sampled in detail for microfossils whose benthic assemblages are reported in Appendix 7 to 10 . Two subunits may be distinguished that are separated by a calcareous pedogenetic crust indicating a period of emersion characterized by arid climatic conditions.

The lower subunit, just above the top of the Calcari a Briozoi Fm., is about 2 meters thick; it consists of $30 \mathrm{~cm}$ of grey clays grading to plane-parallel and cross bedded laminated sands with silty interlayers. Planktonic foraminifers are rare but present throughout the whole succession: Globigerina bulloides, Globigerinita glutinata, Globigerinoides obliquus obliquus, G. ruber, G. trilobus, Globorotalia aemiliana, $G$. bononiensis, $G$. inflata, Neogloboquadrina atlantica, Orbulina universa, Turborotalita quinqueloba. As to benthic assemblages, on the whole foraminifers and ostracods (see Appendix 7 to 9) point to a vegetated infralittoral bottom with fresh water input (Candonidae fragments) coherently with the distribution of the recorded taxa in the Mediterranean sea assemblages (BLANC-VERNET, 1969; BONADUCE et alii, 1975; BREMAN, 1976; LANGER, 1988; SGARRELla et alii, 1985; SGARRELla \& MONCHARMONT ZEI, 1993).

The upper subunit is represented by a 3 metres-thick succession internally subdivided in greenish clays at the base, overlain by siliciclastic sands $(2.5 \mathrm{~m})$ and grey clays at the top. The microfossil content testifies for a change from a lower oligohaline-mesohaline brackish environment with Ammonia tepida, Cyprideis torosa and Ilyocypris gibba, Candonidae (CARBONI et alii, 2002; SANTANGELO et alii, 2010), to a polihaline-marine environment (see Appendix-10), and finally coming back to a mesohaline environment with the oligotypic A. tepida and $C$. torosa assemblage. On the whole, therefore, the succession of section 2 documents deposition in a sector of the Apricena horst shallower than those represented in sections $7,8,9$.

G. inflata, from the lower subunit, testifies an age not older than the Gelasian Stage (biozone MPl6) but admits reference to the Early Pleistocene too, whereas the co-occurrence of $G$. bononiensis is due to reworking. 
No biostratigraphic constraints are available from the upper subunit.

The Serracapriola Fm represents the final stage of the Neogene marine cycle and records a sudden siliciclastic sediment supply from the north-western sector in the frame of the southern Adriatic foredeep evolution, just before its final emersion in the Early Pleistocene (see AucElli et alii, 1997; RoBustelli \& AuCELli, 2001).

\section{MAIN UNCONFORMITIES}

\section{AND STRATIGRAPHIC CORRELATIONS}

Areal distribution and geometric relationships of the above-described lithological units are complex and hardly predictable. With the exception of the calcarenitic and megabreccia lithozones, which show a nearly ubiquitous distribution, all the sedimentary bodies are characterized by strong variations in thickness. This is mainly due, as we will evidence later, to the peculiar morphostructural setting of the Apricena-Poggio Imperiale high, which, at least starting from the end of the megabreccia deposition, was a submerged horst bounded by major E-W trending normal faults, characterized by highly variable sedimentation rates, repeated episodes of no sediment supply and a significant synsedimentary seismic activity.

The Plio-Pleistocene stratigraphic record is characterized by the presence of four main discontinuity surfaces that allow to subdivide the succession in four intervals that may be also related to important stages in the tectono-sedimentary evolution of the study area:

- D1. It corresponds to the angular unconformity that separates the Cretaceous limestones of the Calcare di Bari Fm. and the Miocene Terre Rosse deposits from the Lower Pliocene sediments that, depending on the section, may be represented by the limestone-clay lithozone or by the calcarenite lithozone (fig. 6).

- D2. It corresponds to the stratigraphic top of the megabreccia lithozone. It is an erosional surface, locally incising decimetre- to metre-deep and decametre-large depressions filled alternatively with the barnacle-coral biostromal lithozone, the barnacle horizon or the lower portion of the Calcari a Briozoi Fm. (fig. 25). The sharpness, the common occurrence of Lithophaga borings and locally of Fe-oxide coatings clearly show that the D2 was a rock ground. Within the megabreccia lithozone, several macroscopic and microscopic features allow to reconstruct its diagenetic evolution and thus the genesis of the D2 discontinuity. Such features are widely developed in the uppermost portion of the megabed and progressively decrease downward

- complete induration;

- reddish to yellowish staining.

- microsparitic texture of both matrix and clasts that documents a pervasive recrystallization;

- occurrence of $\mathrm{mm}$ - to $\mathrm{cm}$-sized cavities showing highly irregular morphologies, suggesting an origin by dissolution processes. They often show geopetal infillings, with micritic peloid-bearing reddish sediments in the lower part and calcite cements in the upper one. The latter are polyphase being composed of a thin isopachous rim of prismatic crystals followed by blocky spar. Locally the reddish sediment is organized in pendant laminae with downward convexities

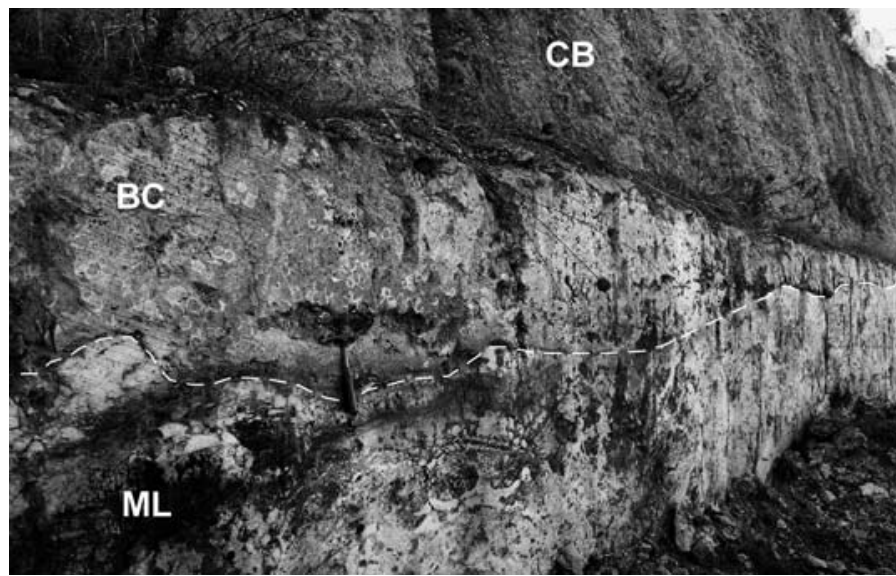

Fig. 25 - A decametre-large depression incised at the top of the megabreccia lithozone (ML) at section 7, and filled with the barnaclecoral biostromal lithozone (BC). CB: Calcari a Briozoi Fm.

- Una depressione di larghezza decametrica al top della megabreccia lithozone $(M L)$ nella sezione 7 , riempita dalla barnacle-coral biostromal lithozone (BC). CB: Calcari a Briozoi Fm.

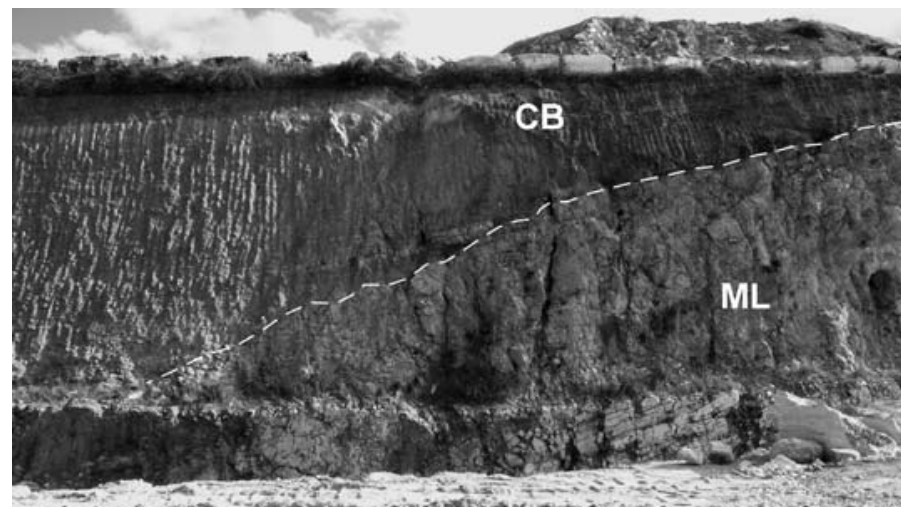

Fig. 26 - Onlap of the Calcari a Briozoi Fm. (CB) on the upper boundary (broken line) of the megabreccia lithozone (ML) at section 7 . - Onlap della Fm. dei Calcari a Briozoi (CB) sulla superficie sommita le (linea tratteggiata) della megabreccia lithozone $(M L)$ nella sezione 7.

These features suggest an early diagenesis in a meteoric environment and hence an episode of subaerial exposure during the time interval corresponding to the D2 unconformity. The truncation of Lithophaga borings, furthermore, documents an erosion likely within littoral environments after colonization.

- D3. It corresponds to the basal boundary of the Calcari a Briozoi Fm. in the eastern sector of the study area (sections 1, 5, 6, 7) and of the Serracapriola sands in the western sector. Its physical expression is a sharp erosional surface extensively bored by Lithophaga, associated to an angular unconformity with onlap geometries of the overlying sediments (fig. 26). Depending on the place, D3 surface cuts each one of the lithologies comprised between the top of the megabreccia and the base of the Calcari a Briozoi or Serracapriola formations (Isognomon biostromal and Glycymeris-bearing lithozones in section 1; Isognomon biostromal lithozone in section 5; barnacle-coral biostromal lithozone in sections 2, 3; barnacle horizon in part of the sections 6,7 ), or can merge with the D2 unconformity surface (part of the sections 6,7 and sections 8,9 ). 


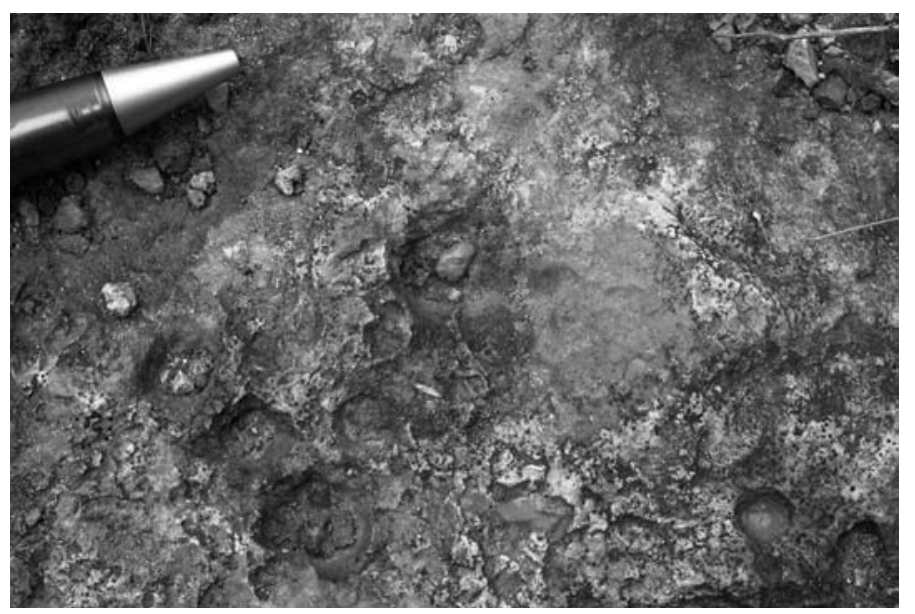

Fig. 27 - Truncated Lithophaga borings at the unconformity surface D4 on the top of the megabreccia lithozone at section 8. Borings are filled with siliciclastic sands of the Serracapriola Fm

- Perforazioni di litodomi sulla superficie di discontinuità D4 a tetto della megabreccia lithozone nella sezione 8. I fori sono riempiti di sabbie silicoclastiche della Fm. di Serracapriola.

- D4. It corresponds to the basal boundary of the Serracapriola Fm. Depending on the place, this discontinuity may overlie the Calcari a Briozoi Fm. (sections 2, 7), the barnacle-coral biostromal lithozone (section 9), or the megabreccia lithozone (sections 8, 9). In particular, in section 2 it corresponds to the hardened layer at the top of the Calcari a Briozoi Fm. that contains rounded, encrusted and bored pebbles of different lithologies (Calcare di Bari limestones, barnacle-coral biostromal limestones, various kinds of calcarenites) which document intense current activity and a prolonged interruption of sediment accumulation. The D4 was a hard ground surface, as testified by the erosional geometries and the local occurrence of Lithophaga borings (fig. 27). The presence of cm-sized cavities geopetally filled with reddish finegrained sediments and calcite spar cements, alike what observed just below the D2 discontitnuity, suggests subaerial exposure.

As far as the age of the sedimentary bodies recognized is concerned, the main bio-chronostratigraphic data, based on planktonic foraminifer assemblages, are here summarized:

- Megabreccia lithozone: subzone MPl4b, i.e. late Zanclean Stage.

- Barnacle-bearing lithozone: subzone MPl4b, i.e. late Zanclean Stage.

- Barnacle-coral biostromal breccia lithozone: latest Zanclean Stage.

- Calcari a Briozoi Fm.: Biozone MP16, corresponding to the Gelasian Stage.

- Serracapriola Fm.: precise data from sections 8 and 9 allow to date it to the Early Pleistocene. The different succession of section 2 instead contain fossils that only allow a generic attribution to the Late Pliocene-Early Pleistocene interval.

By combining biostratigraphic data with the occurrence of discontinuity surfaces, that at the scale of the study area can be considered as time-lines, it is possible to put the four unconformity-bounded intervals in a chronological frame. The first one, comprised between D1 and D2 is referable to the Zanclean. The second interval, comprised between D2 and D3, on the whole refers to the late Zanclean. The third interval, comprised between D3 and D4, corresponds to the Calcari a Briozoi Formation and spans the Gelasian. The complex of sediments encompassing the second and third intervals shows the most relevant changes in thickness and facies and may be even completely lacking where D2, D3, and D4 merge in a single, complex discontinuity at the top of the megabreccia. This is the result of a locally important tectonic activity that deeply affected the stratigraphic record and that will be discussed in the following section. Finally, the fourth interval, overlying the D4, corresponds to the Serracapriola Fm. and dates to Early Pleistocene, though a late Gelasian age can not be excluded.

\section{EVIDENCE OF POLYPHASE SYNDEPOSITIONAL TECTONICS}

The favourable outcrop conditions of the ApricenaLesina-Poggio Imperiale quarrying district allow not only to evidence important lateral facies and thickness changes of sedimentary bodies, but also to directly observe sharp surfaces of tectonic origin that bound sectors characterized by different stratigraphies. The geometric and stratigraphic relationships between these surfaces and the well dated unconformity-bounded intervals enable a detailed reconstruction of the Pliocene tectonosedimentary evolution of the study area to be carried out. In particular, two main tectonic surfaces, E-W trending, have been recognized and will be described.

\section{Southern fault}

Sections 1, 2, 3, 4 are all lined up on the same E-W trending main fault and allow to reconstruct its complex organisation. The best exposure of the southern fault is on section 1 that corresponds to a deep artificial trench now abandoned. The trench is up to about 50 metres deep and is N-S trending, insofar providing a beautiful section across the fault (figs. 28, 29). The displacement across this fault is not measurable, but it surely excedeed 40 metres, i.e. the thickness of sediments on the hangingwall. The footwall is entirely composed of sub-horizontal Calcare di Bari limestones, characterized by an increasing degree of internal fracturation approaching the fault. The core-zone of the fault is represented by a subvertical 4-6 metres thick breccia body: the clasts, all composed of Calcare di Bari limestones, are angular in shape and range in size from some millimetres to few metres; the matrix is a wackestone/packstone with echinoderms, miliolids, benthic foraminifera and bryozoan fragments in which cm-sized barnacle and coral fragments float. Some 20-30 metres southward from the fault a second-order antithetic high-angle normal fault is visible, showing the same strike but opposite dipping direction (fig. 30). The morphological depression, bordered by the main fault and its antithetic fault, is filled up with resedimented deposits among which two bodies are recognizable. The lower body is composed of the barnacle-bearing lithozone organized in dm-thick ill-defined beds with a concaveupward geometry, quickly steepening approaching the fault; on the whole, its geometry is wedge-shaped with the depocentre close to the main fault (fig. 31). This lower 
Fig. 28 - Panoramic view of the southern fault (unbroken line) at section 1, from section 2 . On the left the Calcare di Bari Fm. limestones (CBa) making up the footwall and the thick breccia body along the fault (FB); on the hanging wall to the right, the barnacle-bearing lithozone (B), the barnacle-coral biostromal breccia lithozone (BB) and the yellowish calcarenites of the Calcari a Briozoi Fm. (CB).

- Vista panoramica della faglia meridionale (linea continua) nella sezione 1 , dalla sezione 2 Sulla sinistra, i calcari della Calcare di Bari Fm. $(C B a)$ e la spessa breccia di faglia (FB); a destra, il corpo cuneiforme della barnacle-bearing lithozone (B), la barnacle-coral biostromal breccia lithozone $(B B)$ e le calcareniti giallastre della Fm. dei Calcari a Briozoi (CB).

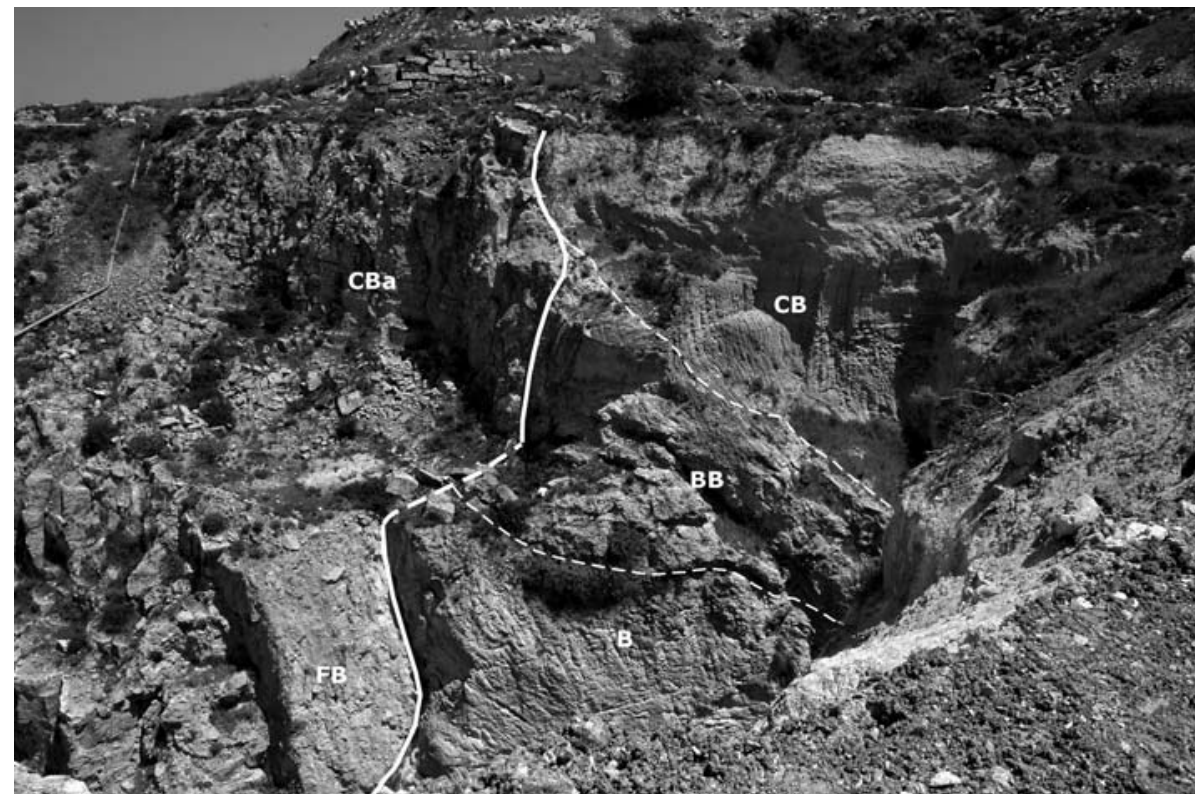

Fig. 29 - Schematic sketch of the geometric relationships observable in the faulting sector at sections $1,2,3$. See also figs. 28 and 30 for comparisons.

- Disegno schematico dei rapporti geometrici osservabili nel settore di faglia delle sezioni 1, 2, 3 . Si confronti con le figg. 28 e 30.

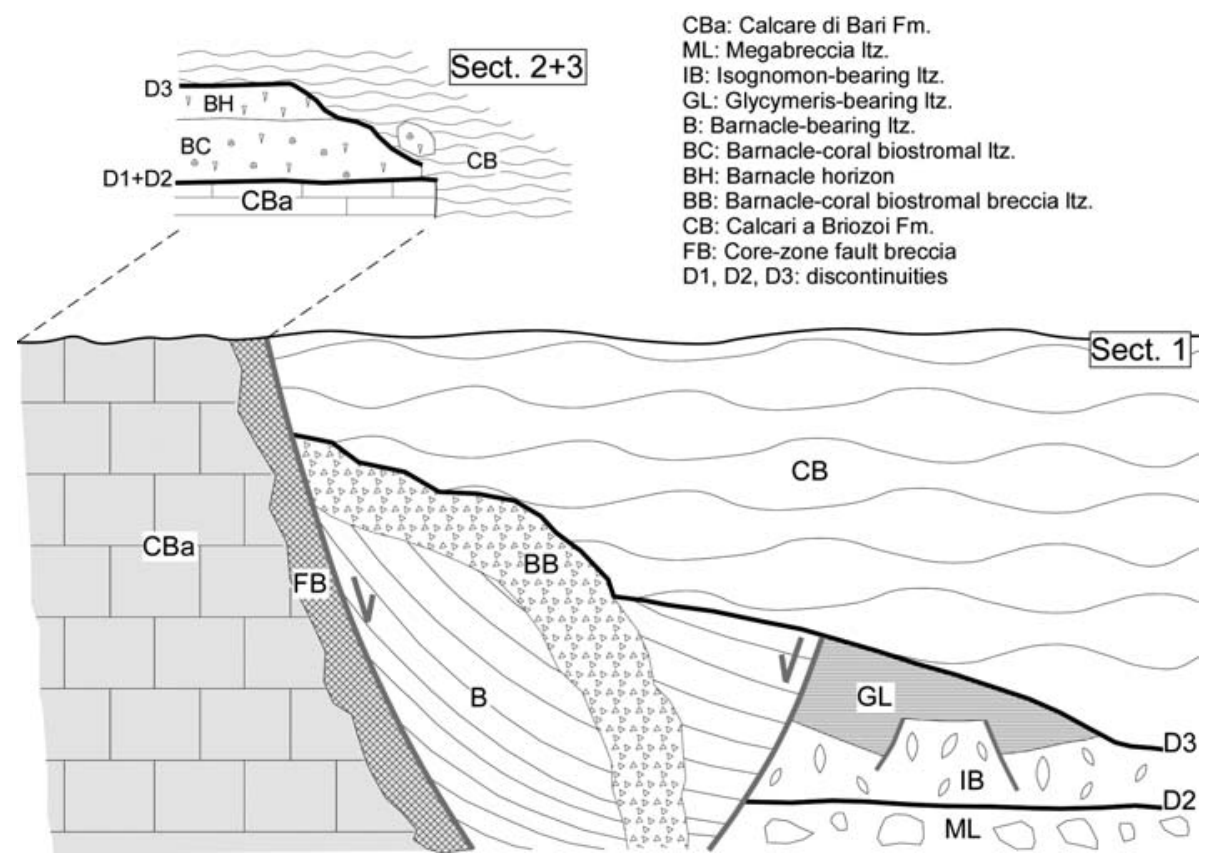

sedimentary body is abruptly crosscut by another breccia body (barnacle-coral biostromal breccia lithozone) that is massive, highly irregular in shape and thickness (from decimetres to 3-4 metres thick), sub-vertical in the lower part of the outcrop but gradually turning to horizontal in the upper part, where it abuts against the main fault.

These two sedimentary bodies, as well as the breccia of the main fault core-zone, are sharply overlain by the yellowish calcarenites of the Calcari a Briozoi Fm., which unconformably rest on them with onlap relationships (fig. 30). Also the southern antithetic fault is sealed by the Calcari a Briozoi calcarenites, and the pre-calcarenite succession, displaced by the fault, here is represented by the Isognomon- and the Glycymeris-bearing lithozones The Isognomon-bearing lithozone stratigraphic top is further variously displaced by a few small-scale E-W trending normal faults, resulting in metre-sized wedge-shaped morphological depressions filled with the basal levels of the Glycymeris-bearing lithozone. On the whole, however, the Glycymeris-bearing lithozone shows a wedge-shaped geometry, with a maximum thickness of about 6 metres close to the antithetic fault, progressively reducing to zero a few hundreds of metres southward, where the Calcari a Briozoi Fm. rests directly on the Isognomon-bearing lithozone. The same geometrical relationships are confirmed along the fault plane strike in section 4 where 


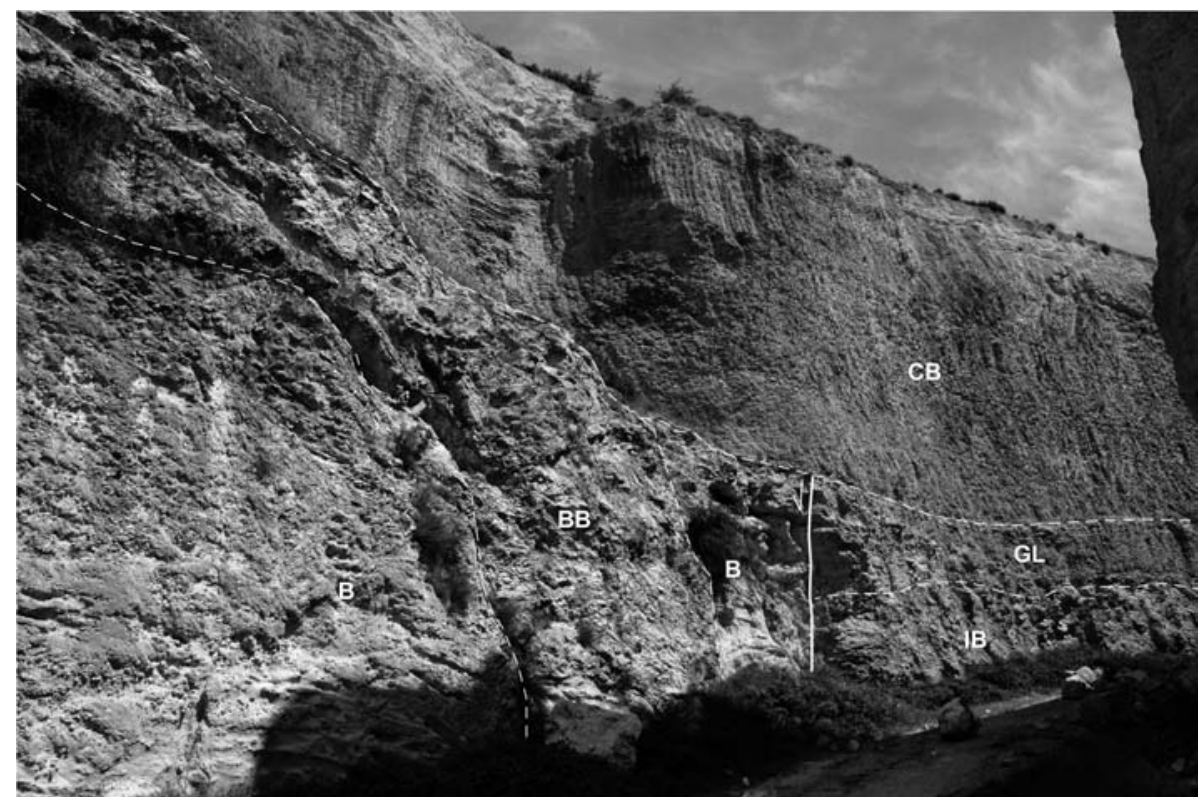

Fig. 30 - A closer view of the hanging wall of fig. 28. In the lower part, from left to right: the barnacle-bearing lithozone (B), abruptly cut by the barnacle-coral biostromal breccia lithozone (BB); the antithetic fault (unbroken line); the Isognomon biostromal lithozone (IB) overlaid by the Glycymeris-bearing lithozone (GL). In the upper part, the yellow calcarenite of the Calcari a Briozoi Fm. (CB), sealing the antithetic fault. For further explanations see the text and the schematic sketch of fig. 29.

- Vista ravvicinata dell'hanging wall di fig. 28 Nella parte inferiore, da sinistra verso destra: la barnacle-bearing lithozone (B) bruscamente tagliato dalla barnacle-coral biostromal breccia lithozone (BB); la faglia antitetica (linea continua); la Isognomon biostromal lithozone (IB) e la Glycymeris-bearing lithozone (GL). Nella parte superiore le calcareniti gialle della Fm. dei Calcari a Briozoi $(C B)$, che sigillano la faglia antitetica. Ulteriori spiegazioni nel testo e nello schema di fig. 29.

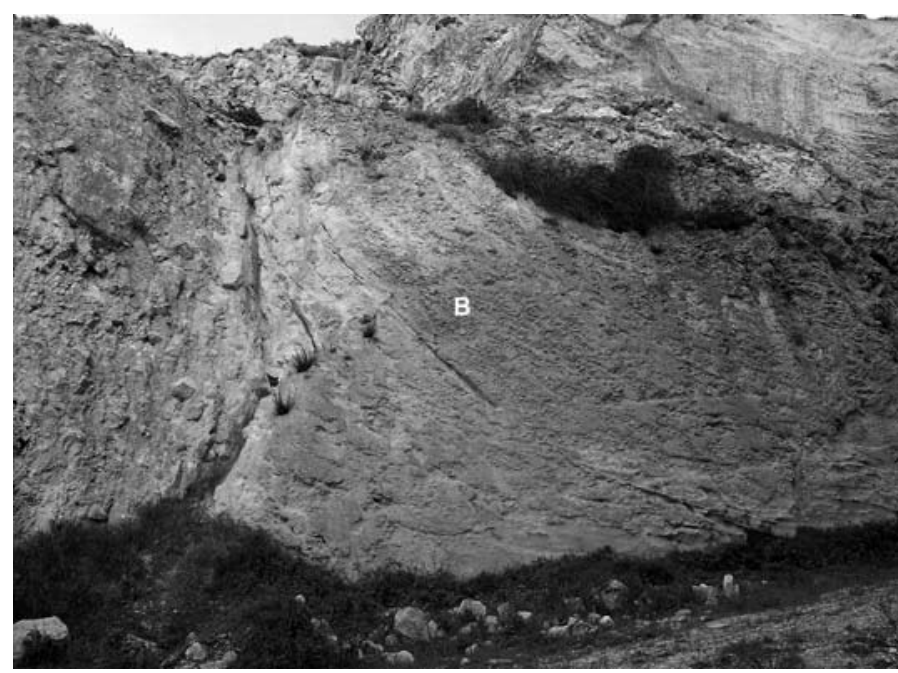

Fig. 31 - The barnacle-bearing lithozone (B) at section 1 is composed of a wedge-shaped body of greenish bioclastic packstones filling the morphological depression limited by the southern fault of the Apricena horst. Note the upward-concave geometry of the beds (see also figs. 16 and 17).

- La barnacle-bearing lithozone (B) della sezione 1 costituisce un corpo cuneiforme composto da calcareniti bioclastiche verdastre, che riempie la depressione morfologica delimitata dalla faglia meridionale dell'horst di Apricena. Si noti la geometria concava verso l'alto degli strati (si vedano anche le figg. 16 e 17).

the barnacle-bearing lithozone abuts against the fault core zone represented by the brecciated Calcare di Bari limestones.

Further evidence of synsedimentary activity derives from section 2, where the erosional upper boundary of the barnacle-coral biostromal lithozone corresponds to the D3 unconformity, overlain by the yellowish calcarenites of the Calcari a Briozoi Fm. The presence of a large block several metres across, detached from the main barnacle-coral biostromal body, slightly tilted and sur- rounded by the calcarenites, clearly testifies for collapse phenomena during the deposition of the Calcari a Briozoi Fm. (fig. 32). In section 3, at last, also the barnacle horizon is present above the barnacle-coral biostromal lithozone.

All the stratigraphic and geometrical features observed in sections 1 to 4 allow to define the timing of the southern fault activity as well as its effects on sedimentation. The main synsedimentary activity is chronologically constrained by the age of the youngest unit displaced by the faults (Glycymeris-bearing lithozone) and the oldest unit sealing the fault planes (Calcari a Briozoi Fm.) i.e. between late Zanclean and Gelasian. During this time span, the accomodation space created by the displacement of the southern block was filled by rock falls and debris flows activated along the unstable edge of the footwall. Two gravitational flow events have been documented in sections 1 and 4 . The oldest is constituted by the barnacle-bearing lithozone which was sourced from the central horst edge where the barnacle palaeocommunity of the barnacle horizon was thriving. The youngest is a lithoclastic breccia composed of clasts deriving from collapse of the barnacle-coral biostromal lithozone. Both resedimented bodies represent the product of multiple gravitational flows probably triggered by seismic shocks related to the fault activity. The occurrence of small-scale normal faults sealed by the Glycymeris-bearing lithozone, observed in section 1, suggests that the main fault activity phase was preceded by other minor faulting events, whereas the slight displacement of the large block embedded in the Calcari a Briozoi of section 2 evidences later albeit minor seismic activity.

\section{Northern fault}

The northern fault shows a much smaller total displacement, with the northern block downthrown from a minimum of 4-5 metres to a maximum of 15-20 metres. It has been observed in sections 6, 7 and 8, and inferred in the area northwards of section 5 . In section 6 and in the 


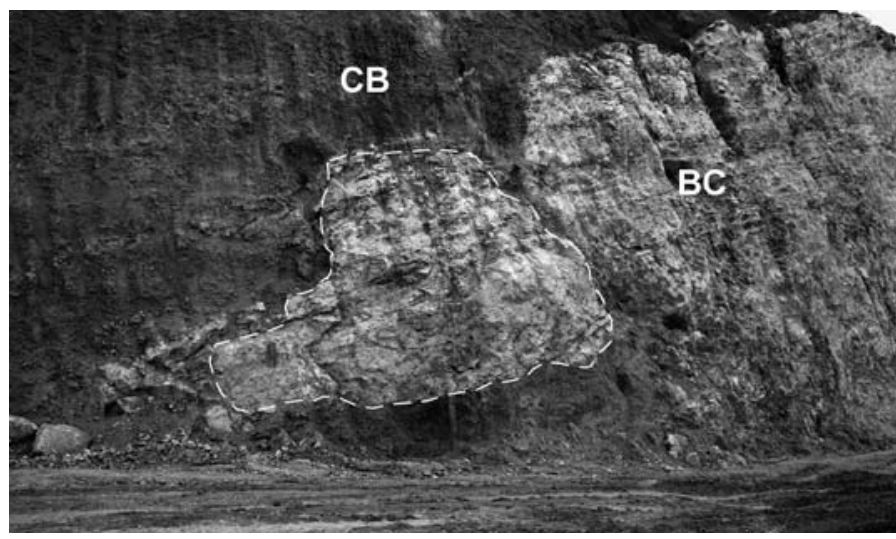

Fig. 32 - The barnacle-coral biostromal lithozone (BC) at section 2 is decametre-thick and internally organized in massive beds. The erosive upper boundary corresponds to the D3 unconformity overlaid by the Calcari a Briozoi Fm. (CB). Note on the left the presence of a large megablock (broken line), detached from the main biostrome body and surrounded by the calcarenite.

- La barnacle-coral biostromal lithozone (BC) nella sezione 2 raggiunge uno spessore decametrico ed è organizzata in strati massivi. Il limite superiore è una superficie erosiva corrispondente alla discordanza $D 3$, su cui si appoggia la Fm. dei Calcari a Briozoi (CB). Si noti sulla sinistra la presenza di un megablocco (linea tratteggiata), distaccato dal biostroma principale e circondato dalla calcarenite.

eastern sector of section 7 the footwall block is uniquely made up of intensely fracturated Calcare di Bari limestones, whereas in the downthrown block the Lago di Varano and the Calcari a Briozoi formations are also visible. The Lago di Varano Fm. is here characterized by a wedge-shaped geometry, with the thickest portion close to the fault plane. The top is slightly tilted northward and the overlying Calcari a Briozoi Fm. climb on it with onlap geometric relationships (fig. 33). In the western sector of section 7 the fault cuts across the megabreccia, downthrowing it northward by about 4 metres. Close to the main fault, the downthrown block is further dissected by a metre-scale south-dipping antithetic fault; the resulting rugged surface is irregularly draped by a thin layer of the Calcari a Briozoi Fm. These calcarenites are in turn over-

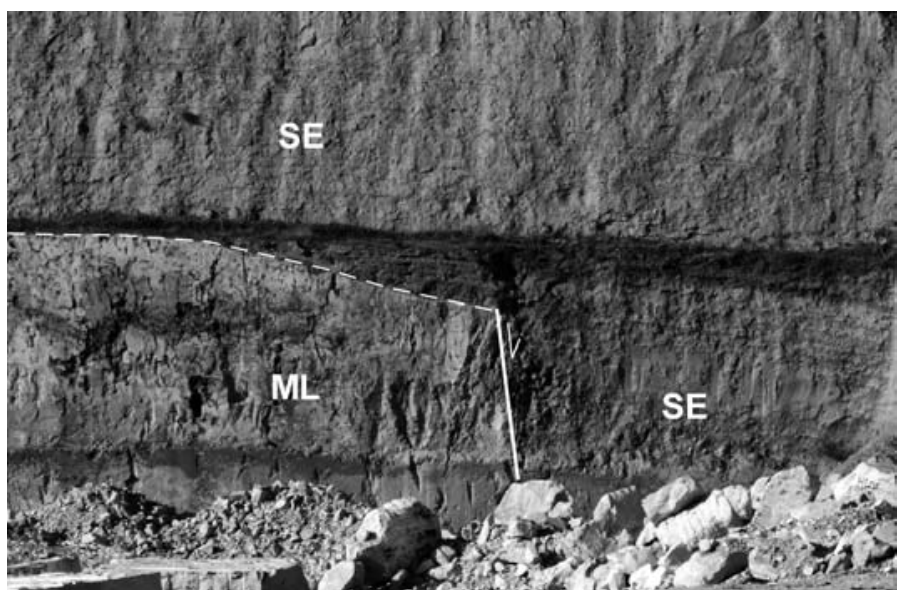

Fig. 34 - The northern fault (unbroken line) at the westernmost sector of section 7, displacing the megabreccia lithozone (ML) and sealed by the Serracapriola Fm. (SE).

- La faglia settentrionale (linea continua) nel settore occidentale della sezione 7 disloca la megabreccia lithozone $(M L)$ ed è sigillata dalla Fm. di Serracapriola (SE).

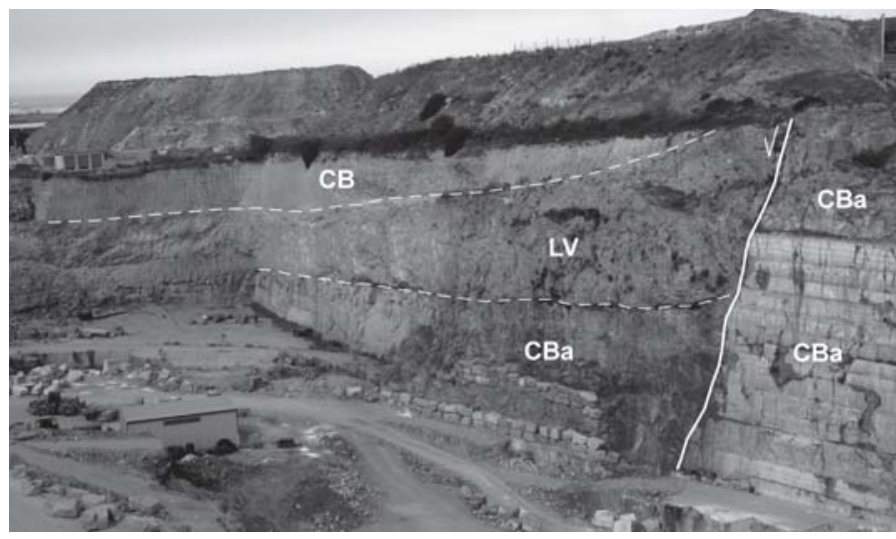

Fig. 33 - Panoramic view of the northern fault (unbroken line) at section 6. Note the onlap geometric relationships between the Calcari a Briozoi Fm. (CB) and the underlying Lago di Varano Fm. (LV). CBa: Calcare di Bari Fm.

- Vista panoramica sulla faglia settentrionale (linea continua) nella sezione 6. Si notino i rapporti geometrici di onlap tra la Fm. dei Calcari a Briozoi $(C B)$ e la sottostante Fm. del Lago di Varano (LV). CBa: Fm. di Calcare di Bari.

lain by the Serracapriola Fm., which seals the main fault leaning on the southern footwall block with onlap geometric relationships (fig. 34). In the proximity of the fault, both blocks are crossed by a complex network of sub-vertical dykes, up to several decimetres wide. The dykes of the hangingwall are filled with the yellowish calcarenites, whereas the footwall dykes are filled with the Serracapriola sandstones.

The stratigraphic and geometric features observed in sections 6 and 7 suggest a timing for the northern fault activity closely similar to the one inferred for the southern fault. The main synsedimentary tectonic phase took place after the deposition of the megabreccia and before the deposition of the Calcari a Briozoi Fm., which seals the fault and fills up the related sea-floor depressions. As discussed in the previous chapter (Main unconformities and stratigraphic correlations), from $\mathrm{E}$ to $\mathrm{W}$ the yellowish calcarenites progressively reduce their thickness, so that in the western sector of section 7 the morphological relief created by the fault displacement was not filled until the deposition of the Serracapriola sandstones.

\section{DISCUSSION AND CONCLUSIONS}

On the basis of biochronostratigraphic, palaeoecological and sedimentological data, genetic interpretation of discontinuity surfaces, and the geometrical relationships of sedimentary bodies, that may be directly related to observed tectonic structures, the following steps in the Pliocene to Early Pleistocene tectono-sedimentary evolution of the Apricena-Poggio Imperiale area may be sketched:

a) After the prolonged period of subaerial exposure which led to the intense karstification of the Mesozoic Calcare di Bari limestones and the production of the residual Upper Miocene-Lower Pliocene Terre Rosse, marine sedimentation started again during the Zanclean in a lagoonal depositional environment (limestone-clay litho- 
zone), rapidly evolving to a middle to upper shoreface setting (calcarenite lithozone). The occurrence of a 4-6 metres-thick megabed with sedimentological features pointing to a tsunami event testifies for a very large seismic shock in the proximity of the Apricena-Poggio Imperiale area, possibly related to the activity of some major geodynamic elements (e.g.: the Mattinata Fault System).

b) The megabed deposition was followed by a subaerial exposure episode, which determined a widespread and intense early meteoric diagenesis of sediments. The subsequent marine depositional phase, spanning the Late Zanclean, was strongly controlled by synsedimentary tectonics that originated a highly irregular sea floor topography. This resulted in variations both in facies and stratigraphic thicknesses, and in complex geometric relationships between the different lithozones. More in detail, after the deposition of the Isognomon biostromal and Glycymerisbearing lithozones, whose patchy distribution is mainly due to ecological constraints, the activation of km-scale E-W trending normal faults provoked the uplift of a horst sector, elevated on the surrounding areas by several tens of metres. Marine transgression was rapid, so that the central horst was placed below the infralittoral/circalittoral transition, and sedimentation was represented exclusively by the growth of barnacle-coral biostromes and barnacle communities (barnacle-coral biostromal and barnacle horizon lithozones). Thickness and continuity of such bioconstructed bodies progressively reduce westward, thus suggesting less favourable ecological conditions in the western sectors of the horst, possibily related to greater dephts of the sea floor. The edges of the horst, close to the boundary faults, were repeatedly affected by gravitational collapse phenomena, involving all the terms of the succession. The highest parts of the resulting escarpments were locally covered by barnacle-coral biostromes that could give raise to decametre-thick bodies (see section 2), being favoured by the strong and continuos currents active along the edges. Such early lithified bodies were in turn affected by mechanical erosion and rock falls events; the overlying unconsolidated barnacle communities, on the contrary, were swept off giving rise to debris flows moving down fault slopes. All these gravitational deposits filled the morpho-structural depressions created by the displacement along the main fault and the contemporaneous activation of minor antithetic faults dissecting the hanging wall blocks (see section 1).

c) Another discontinuity testifies for an ubiquitous erosional phase and is overlain with onlap geometries by the calcarenites of the Calcari a Briozoi Fm. The latter fill up the remaining tectonic depressions, and seal the horst boundary faults. Even if evidence for rock fall phenomena during calcarenite deposition, possibly triggered by seismic shocks, are locally documented, the Calcari a Briozoi Fm., dated to the Gelasian, marks the end of the main synsedimentary tectonic phase within the ApricenaPoggio Imperiale area. These data fit well with the observations of SPALluto \& MoRETTI (2006), that pointed out the occurrence of synsedimentary Pliocene extensional features (metre-scale grabens, neptunian dikes) in the Masseria Zingari locality, just a few hundreds of metres south of the study area. Palaeoecological data document a regressive trend within the calcarenites, passing from a circalittoral setting at the base to a inner infralittoral environment at the top. Moving westward, the Calcari a Briozoi Fm. progressively reduces its thickness and finally pinches out, thus testifying for sediment starvation in the western sector during the Gelasian.

d) The Serracapriola Fm. rests on a discontinuity associated to diagenetic evidence for a prolonged subaerial exposure; the erosional effects related to such discontinuity were much more effective in the westermost sector, where the Serracapriola Fm. directly overlies the megabreccia lithozone. The Serracapriola Fm. marks an abrupt change in sedimentation: the sudden siliciclastic sediment supply from the north-western sector documents the approaching of the Apennines and the involvement of the Apricena-Poggio Imperiale area within the southern Adriatic foredeep.

e) The final emersion of the area was followed by the development of an extensive karst network, that was much more branched and diversified in the morphologically highest sectors of the former Apricena horst, i.e. in the present Dell'Erba's quarries where the calcareniticsiliciclastic cover is reduced or absent (ABBAzZI et alii, 1996, fig. 4). The hypogeous mechanisms developed (1) after reactivation of the pre-Pliocene palaeokarst structures or (2) by new conduits that passed through the Pliocene carbonates to reach the contact on the Calcare di Bari Fm. (fig. 23). The meteoric dissolution was more effective along the highly-fractured core-zones of the synsedimentary Pliocene faults, leading to the opening of large karstic features (sinkholes and funnel-like depressions). The water flows circulating within such cavities led to their infilling by sandy-clayey sediments, clasts and biogenic products, among which the recently recovered human artifacts are the most impressive (ARZARELLO et alii, 2007, 2009).

f) The late Villafranchian age of the vertebrate Pirro Nord F.U. is definitely younger than the late Gelasian (?)Early Pleistocene age of the basal Serracapriola Fm., as inferred from microfossil and brachiopod assemblages. No more precise chronostratigraphic constraints are presently available; also the palaeomagnetic results are limited and can only testify the Matuyama reversed Chron (TEMA et alii, 2009). However, possible clarification could derive from the U/Th-ESR-combined radiometric tests in progress at the Laboratoire de Préhistoire du Muséum National d'Histoire Naturelle de Paris on the mammal tooth enamel of specimens collected during the 2007 field work.

\section{ACKNOWLEDGEMENTS}

Field works were financially supported by University Ministry grants 2006044074_002 (resp. G. Pavia, Torino) and 2006044074_001 (resp. C. Petronio, Roma), and by Italcementi Groups, Cassa di Risparmio Foundation, San Paolo Foundation. Special thanks to C. Petronio (Roma Sapienza University) who read an early draft of the manuscript and provided useful suggestions, and to D. Violanti and L. De Bortoli (Torino University) for contributing micropalaeontological data. We are grateful to many colleagues who joined us in field inspections: G. Robustelli (Calabria University), M. Arzarello (Ferrara University), P. Aucelli (Molise University), M. Mancini, C. Petronio, R. Sardella (Roma Sapienza University), F. Marcolini (Roma 3 University).

\section{APPENDIX}

1 - Microbenthos content of the barnacle-bearing lithozone at section 1.

Foraminifera: Bolivina leonardii, Cibicidoides pachyderma, Elphidium spp., Gyroidina neosoldanii, Lenticulina cultrata, Melonis barleeanum, Orthomorphina bassanii, Planulina ariminiensis, Pleu- 
rostomella alternans, Siphonina planoconvexa, Sphaeroidina bulloides, Textularia sagittula, Uvigerina longistriata. Ostracoda: Acanthocythereis hystrix, Argilloecia sp., Bytocythere cf. minima, Costa edwardsi, Eucytherura gibbera, Henryhowella sarsi, Occultocythereis dohrni, Pterigocythereis jonesi, Semicytherura alifera, Triebelina aff. raripila.

2 - Fossil content in the lowermost Calcari a Briozoi Fm.

a) Section 3 - Brachiopoda: Joania cordata, Megathiris detruncata, Terebratula sp., Terebratulina retusa. Gastropoda: Patella cf ferruginea, Astraea rugosa molds. Pelecypoda: Arca noae molds, bivalve Pinna sp., Lima lima, Chlamys multistriata, C. opercularis, C. pesfelis, Pecten jacobaeus, Ostrea lamellosa, Hinnites crispus, Spondylus gaederopus, Thyasira sp. molds, Tellina sp. molds.

b) Section 1 - Foraminifera: abundant Cibicides lobatulus and Neoconorbina terquemi with Ammonia parkinsoniana, Asterigerinat planorbis, Bulimina costata, Cibicidella irregularis, Cibicidoides pachy derma, Dorothia gibbosa, Elphidium complanatum, E. macellum, Florilus boueanum, Fissurina sp., Globocassidulina oblonga, Melonis barleeanum, Quinqueloculina viennensis, Uvigerina peregrina.

3 - Microbenthos content in the topmost Calcari a Briozoi Fm. at section 2.

Foraminifera: Ammonia beccarii, Cibicides lobatulus, Elphidium crispum. Ostracoda: Costa batei, Cytherella robusta, Grinoides heidingeri, Loxoconcha gr. bairdi, Pontocythere turbida, Semicytherura alifera, Urocythereis sororcula.

4 - Gastropod content in the Calcari a Briozoi Fm. at section 9.

Fossils show little dimensions due to selection: Calliostoma multilamellare, Bolma granosa, Homalopoma sp., Alvania sp., Schilderia utriculata, Naticidae sp., Oochorys sp., Muricidae sp.ind., Anachis turbinellus, Nassarius sp., Mitra sp., Turbonilla sp.

5 - Microbenthos content at the very base of the Serracapriola Fm. at section 8.

Foraminifera: Ammonia parkinsoniana, Bolivina alata, Bulimina echinata, B. marginata, Cibicidella irregularis, Cibicides lobatulus, Cibicidoides pachyderma, Dorothia gibbosa, Elphidium aculeatum, E. crispum, Fissurina orbignyana, Florilus boueanum, Lenticulina rotulata, Oolina striata, Pullenia quinqueloba, Quinqueloculina sp., Textularia sp., Valvulineria bradyana. Ostracoda: Aurila punctata, Aurila sp., Cytherella robusta, Cytheropteron ruggierii, Echinocythereis postulata, Leptocythere rara, Loxoconcha turbida, Semicytherura incongruens.

6 - Microbenthos content in the lower Serracapriola Fm. at section 8 , about 8 metres above the sample 5 .

Foraminifera: common Ammonia beccarii, Cassidulina carinata Cibicides lobatulus, Elphidium advenum, E. complanatum, E. crispum, E. decipiens, E. macellum, E. poyeanum, E. pulvereum, together with Ammonia gaimardi, A. parkinsoniana, A. tepida, Asterigerinata mamilla, Bolivina albatrossi, $B$. catanensis, $B$. dilatata, $B$ spathulata, Buccella granulata, Bulimina costata, B. marginata, Cibicidoides pachyderma, Discorbinella berthelothi, Globocassidulina subglobosa, Melonis barleeanum, Neoconorbina terquemi, Nonion boueanum, Nonionella turgida, Planulina ariminiensis, Plectofrondicularia semicosta, Pullenia bulloides, Quinqueloculina viennensis Rosalina floridana, Stilostomella adolphina, Textularia sp., Uvigerina peregrina, Valvulineria bradyana. Ostracoda: scarce Leptocythere bacescoi, L. rara, Loxoconcha ovulata, Pontocythere turbida.

7 - Microbenthos content in the lower part of the lower Serracapriola Fm. at section 2.

Foraminifera: abundant Ammonia beccarii, Elphidium crispum, Cibicides lobatulus, together with Asterigerinata mamilla, A planorbis, Buccella granulata, Cancris auriculus, Cibicidella irregularis, Elphidium aculeatum, E. complanatum, E. macellum, Gyroidina neosoldanii, Globocassidulina subglobosa, Nonion boueanum, Planulina ariminiensis, Rosalina floridana, $R$. obtusa, $R$. bradyi, Stainforthia complanata. Ostracoda: Aurila aff. nimbosa, Aurila aff. puncti cruciata, Cytheretta semiornata, Falsocythere maccagnoi, Hemicytherura defiorei, Loxoconcha rhomboidea, Mutilus elegantulus, M. pygadiana, Pachycaudites ungeri, Rectotrachyleberis elegans.

8 - Microbenthos content in the lower-middle part of the lower Serracapriola Fm. at section 2 .

Foraminifera: to the list of the previous assemblage we add, among the accessory species, Bolivina catanensis, $B$. dilatata, $B$. plicatella, Cassidulina carinata, Fissurina sp., Fursenkoina acuta, Neoconorbina orbicularis. Ostracoda: Callistocythere littoralis, C. intricatoides, $C$. pallida, Caudites calceolatus, Cimbaurila vitrocincta,
Eucytherura partecoli, Hemicytherura defiorei, Henryhowella sarsi, Loxoconcha oculata, Paracytheridea bovettensis, Pontocythere turbida, Urocythereis aff. favosa.

9 - Microbenthos content in the middle part of the upper Serracapriola Fm. at section 2 .

Foraminifera: Cibicides lobatulus, Elphidium macellum, Rosalina floridana are the most abundant species. Ostracoda: Aurila convexa, A. puncticruciata, Callistocythere flavidofusca, C. littoralis, Cytherelloidea backmanni, Eucytherura gibbera, E. complexa, Hemicytherura gracilicosta, $H$. defiorei, Leptocythere bacescoi, L. rara, Loxoconcha rhomboidea, L. ovulata, Mutilus laticancellatus, Occultocythereis dohrni, Pachycaudites h-scripta, Pontocythere turbida, Semicytherura alifera, S. cribriformis, S. incongruens, S. ruggierii, Tetracytherura angulosa, Xestoleberis plana, X. communis.

10 - Ostracod content in the middle part of the upper Serracapriola Fm. at section 2 .

Callistocythere littoralis, Cyprideis torosa, Cytherideis napoletana Leptocythere bacescoi, L. ramosa, L. rara, Loxoconcha oculata, L. rhomboidea, Pontocythere turbida, Semicytherura incongruens, S. rara, Urocythereis sp., Xestoleberis dispar.

\section{REFERENCES}

Abbazzi L., Benvenuti M., Boschian G., Dominici S., Masini F. Mezzabotta C., Piccini L., Rook L., Valleri G. \& Torre D (1996) - Revision of the Neogene and Pleistocene of the Gargano region (Apulia, Italy). The marine and continental successions and the mammal faunal assemblages in an area between Apricena and Poggio Imperiale (Foggia). Mem. Soc. Geol. It., 51, 383-402.

arzarello M., Marcolini F., Pavia G., Pavia M., Petronio C., PeTRUCCI M., ROOK L. \& SARDElla R. (2007) - Evidence of earliest human occurrence in Europe: the site of Pirro Nord (Southern Italy). Naturwissenschaften, 94, 107-112.

Arzarello M., Marcolini F., Pavia G., Pavia M., Petronio C., PeTRUCCI M., ROOK L. \& SARDELla R. (2009) - L'industrie lithique du site Pléistocène inférieur de Pirro Nord (Apricena, Italie du sud): une occupation humaine entre 1,3 et 1,7 Ma. l'Anthropologie, 113, 47-58.

Azzaroli A. (1968) - Calcarenite di Gravina. Studi illustrativi della Carta Geologica d'Italia. Formazioni geologiche. Fascicolo 1, 183-187.

Aucelli P.P.C., Cinoue A. \& Robustelli G. (1997) - Evoluzione quaternaria del tratto di avanfossa appenninica compreso tra Larino (Campobasso) e Apricena (Foggia). Dati preliminari. Il Quaternario, 10, 453-460.

BLANC-VERnet L. (1969) - Contribution à l'étude des foraminifères de Méditerranée. Travaux de la Station Marine d'Endoume, Marseille, Thèse de Doctorat Etat, $281 \mathrm{p}$

Bonaduce G., Ciampo G. \& Masoli M. (1975) - Distribution of Ostracoda in the Adriatic Sea. Pubbl. Staz. Zool. Napoli, 40 suppl., $304 \mathrm{p}$.

Boni A., Casnedi R., Centamore E., Colantoni P., Cremonini G., Elmi C., Monesi A., Selli R. \& Valletta M. (1969) - Note Illustrative della carta Geologica d'Italia alla scala 1:100000. Foglio 155: S. Severo. Serv. Geol. Italia, $46 \mathrm{p}$

Bosellini A. \& Neri C. (1995) - L'Eocene di Monte Saraceno (Promontorio del Gargano, Puglia). Ann. Univ. Ferrara, 6, 27-40.

Bosellini A., Neri C. \& LuCIANI V. (1994) - Platform margin collapses and sequence stratigraphy of slope carbonates (CretaceousEocene, Gargano Promontory, Southern Italy). $15^{\text {th }}$ IAS Regional Meeting, Ischia, Italy. Field guide book, 127-161.

BRANCKMAN C.M. \& AYDIN A. (2004) - Uplift and contractional deformation along a segmented strike-slip fault system: the Gargano Promontory, southern Italy. Journ. Struct. Geol., 26, 807-824.

BREMAN E. (1976) - Distribution of ostracodes in the bottom sediments of the Adriatic Sea. Acad. Proefschr. Vrije Univ. Amsterdam, $165 \mathrm{p}$.

Cantalamessa G. \& Di Celma C. (2005) - Sedimentary features of tsunami backwash deposits in a shallow marine Miocene setting, Majillones Peninsula, nothern Chile. Sedim. Geol., 178, 259-273.

Capuano N., Pappafico G. \& Augelli G. (1996) - Ricostruzione de sistemi deposizionali plio-pleistocenici del margine settentrionale dell'avanfossa pugliese. Mem. Soc. Geol. It., 51, 27-292. 
Carboni M.G., Bergamin L., Di Bella L., Iamundo F. \& Pugliese N. (2002) - Palaeoecological evidences from foraminifers and ostracods on Late Quaternary sea-level changes in the Ombrone river plain (central Tyrrhenian coast, Italy). Geobios, 35, Supplement $1,40-50$.

CASNEDi R. (1988) - Sedimentazione e tettonica pliocenica nel sottosuolo della bassa valle del Fortore (Foggia). Mem. Soc. Geol. It., 19, 605-612.

Casolari E., Negri A., Picotti V. \& Bertotti G. (2000) - Neogene stratigraphy and sedimentology of the Gargano Promontory (southern Italy). Eclogae Geol. Helv., 93, 7-23.

Chaix C., Cahuzac B. \& Cluzard A. (1999) - Les scléractiniares du Serravallien de Pessac (nord-aquitaine, France); approche paléoécologique. Geobios, 32 (1), 33-62.

Chilovi C., De Feyter A.J. \& Pompucci A. (2000) - Wrench zone reactivation in the Adriatic block: the example of the Mattinata Fault System (SE Italy). Boll. Soc. Geol. It., 119, 3-8.

Cita M.B. (1975) - Studi sul Pliocene e gli strati di passaggio dal Miocene al Pliocene. VII. Planktonic foraminiferal biozonation of the Mediterranean Pliocene deep sea record: a revision. Riv. Ital. Paleontol. Strat., 81, 527-544.

Cremonini G., Elmi C. \& Selli R. (1971) - Note Illustrative della carta Geologica d'Italia alla scala 1:100000. Foglio 156: S. Marco in Lamis. Serv. Geol. Italia, $64 \mathrm{p}$.

D’Alessandro A., Laviano A., Ricchetti G. \& Sardella A. (1979) Il Neogene del Monte Gargano. Boll. Soc. Paleont. It., 19, 9-116.

De Giuli C., Masini F. \& Torre D. (1987a) - The latest Villafranchian faunas in Italy: the Pirro Nord Fauna (Apricena, Gargano). Palaeont. Italica, 74, 52-62.

De Giuli C., Masini F., Torre D. \& Boddi V. (1987b) - Endemism and bio-chronological reconstructions: the Gargano case history. Boll. Soc. Paleont. It., 25, 267-276.

De Giuli C., Masini F. \& Torre D. (1990) - Island endemism in the eastern Mediterranean mammalian paleofaunas: radiation patterns in the Gargano paleo-arcipelago. Atti Acc. Naz. Lincei, 85 247-262.

DE GIULi C. \& TORRE D. (1984) - Species interrelationships and evolution in the Pliocene endemic faunas of Apricena (Gargano Peninsula, Italy). Geobios, mém. Spéc., 8, 379-383.

EINSELE G. (1998) - Event stratigraphy: recognition and interpretation of sedimentary event horizons. In Doyle P. \& Bennet M.R. Eds., Unlocking stratigraphical record: advances in modern stratigraphy, John Wiley \& Sons Ltd., 145-193.

FERNANDEZ-LOPEZ S. (1991) - Taphonomic concepts for a theoretical biochronology. Rev. Espan. Paleont., 6, 37-49.

FERRERo E. \& PAVIA G. (1996) - La successione marina pre-villafranchiana. In Carraro F., Ed., Revisione del Villafranchiano nell'area-tipo di Villafranca d'Asti. Il Quaternario, 9, 36-38.

Freudenthal M. (1971) - Neogene vertebrates from the Gargano Peninsula, Italy. Scripta Geol., 3, 1-10.

Freudenthal M. (1976) - Rodent stratigraphy of some Miocene fissure fillings in Gargano (prov. Foggia, Italy). Scripta Geol., 27 $1-23$.

Gliozzi E., Abbazzi L., Azzaroli A., Caloi L., Capasso Barbato L., Di Stefano G., Esu D., Ficcarelli G., Girotti O., Kotsakis T., Masini F., Mazza P., Mezzabotta C., Palombo M.R. Petronio C., Rook L., Sala B., Sardella R., Zanalda E. \& TORRE D. (1997) - Biochronology of selected mammals, molluscs and ostracods from the Middle Pliocene to the Late Pleistocene in Italy. The state of the art. Riv. It. Paleont. Strat., 90, 369-388.

Guidoboni E. \& TinTi S. (1988) - A review of the historical 1627 tsunami in the southern adriatic. Science Tsunami Haz., 6, 11-16.

Hartley A., Howell J., Mather A.E. \& Chong G. (2001) - A possible Plio-Pleistocene tsunami deposit, Hornitos, nothern Chile. Rev. Geol. Chile, 28 (1), 117-125.

JORISSEN F.J. (1987) - The distribution of benthic foraminifera in the Adriatic Sea. Marine Micropaleont., 12, 21-48.

Kamp P.J.J., HaRmsen F.J., CAMPBell N.S. \& Boyle S.F. (1988) Barnacle-dominated limestone with giant cross-beds in a non-tropical. Tide-swept, Pliocene forearc seaway, Hawke's Bay, New Zealand. Sedim. Geol., 60, 173-195.

LANGer M. (1988) - Recent epiphytic Foraminifera from Vulcano (Mediterranean Sea). Revue Paléobiol., vol. spec. 2, 827-832.
Le Roux J.P. \& VARgas G. (2005) - Hydraulic behavior of tsunami backflows: insights from their modern and ancient deposits. Environ. Geol., 49, 65-75.

Masini F., AbBazzi L., SAla B. \& Torre D. (1998) - Review and new finds of Microtus (Allophaiomys) (Rodentia, Arvicolidae) from the Early Pleistocene of the Italian peninsula. Paludicola, 2, 78-90.

Masini F., Petruso D., Bonfiglio L. \& Mangano G. (2008) - Origination and extinction patterns of mammals in three central Western Mediterranean islands in the Late Miocene to Quaternary. Quater. Internat., 182, 63-79.

MASINI F. \& SALA B. (2007) - Large- and small-mammal distribution patterns and chronostratigraphic boundaries from the Late Pliocene to the Middle Pleistocene of the Italian peninsula. Quater. Internat., 160, 43-56.

MASSARI F. \& D'AlESSANDRO A. (2000) - Tsunami-related scour-anddrape undulations in Middle Pliocene restricted-bay carbonate deposits (Salento, southern Italy). Sedim. Geol., 135, 265-281.

Massari F., Ghibaudo G., D'Alessandro A. \& Davaud E. (2001) Water-upwelling pipes and soft-sediment-deformation structures in lower Pleistocene calcarenites (Salento, southern Italy). GSA Bulletin, 113 (5), 545-560.

Mazza P. \& Rustioni M. (1996) - The Turolian fossil artiodactyls from Scontrone (Abruzzo, Central Italy) and their paleoecological and paleogeographical implications. Boll. Soc. Paleont. It., 35 93-106.

Mazza P. \& Rustioni M. (2008) - Processes of island colonization by Oligo-Miocene land mammals in the central Mediterranean: new data from Scontrone (Abruzzo, Central Italy) and Gargano (Apulia, Southern Italy). Palaeogeogr., Palaeoclim., Palaeoecol., 267, 208-215.

Merla G., Ercoli A. \& Torre D. (1969) - Note Illustrative della car ta Geologica d'Italia alla scala 1:100000. Foglio 164: Foggia. Serv. Geol. Italia, $22 \mathrm{pp}$

Monegatti P. \& RAFFi S. (2001) - Taxonomic diversity and stratigraphic distribution of Mediterranean Pliocene bivalves. Palaeogeogr., Palaeoclimat., Palaeoec., 165, 171-193.

Morigi C., Jorissen F.J., Fraticelli S., Horton B.P., Principi M., Sabbatini A., Capotondi L., CuRzi P.V. \& Negri A. (2005) Benthic foraminiferal evidence for the formation of the Holocene mud-belt and bathymetrical evolution in the central Adriatic Sea. Marine Micropaleont., 57, 25-49.

Nelson C.S., Hyden F.M., Keana S.L., Leask W.L. \& Gordon D (1988) - Application of bryozoan zoarian growth-form studies in facies analysis of non-tropical carbonate deposita in New Zealand. Sedim. Geol., 60, 301-322.

Pampaloni R. (2001) - Formazione del Lago di Varano. In Delfrat et alii (coord.): Carta Geologica d'Italia 1:50000, Catalogo delle Formazioni, Fascicolo II, Unità non validate. Quad. Serv. Geol. Italia, 7, 144-148, SELCA.

Patacca E. \& Scandone P. (2004) - The 1627 Gargano earthquake (Southern Italy): identification and characterization of the causative fault. Journ. Seismol., 8, 259-273.

Pavia G., Arzarello M., Marcolini F., Pavia M., Petronio C., PeTRUCCI M., ROOK L. \& SARDELla R. (2008) - Ricerche antropologiche, paleontologiche e stratigrafiche sul sito pleistocenico di Pirro Nord, Foggia: evidenze della più antica occupazione umana in Europa. Geoing. Ambient. Min., 2008, 149-153.

PAVIA G. \& ZUNINO M. (2008) - Progetto di geoconservazione sul sito a brachiopodi del Pliocene inferiore di Capriglio (Asti). Geol. Romana, 41, 19-24

Péres G.M. \& PiCARD J. (1964) - Nouveau manuel de bionomie benthique de la Mer Méditerranée. Rec. Trav. Stat. Marine Endoume, 31/47, $137 \mathrm{p}$.

PICCARDI L. (2005) - Paleoseismic evidence of legendary earthquakes: the apparition of Archangel Michael at Monte Sant'Angelo (Italy). Tectonophysics, 408, 113-128.

Ricchetti G., Ciaranfi N., Luperto Sinni E., Monelli F. \& Pieri P. (1992) - Geodinamica ed evoluzione sedimentaria e tettonica dell'Avanpaese Apulo. Mem. Soc. Geol. It., 41, 57-82.

Robustelli G. \& Aucelli P.P.C. (2001) - I termini di chiusura del bacino pugliese (Avanfossa sud-appenninica nell'area di Poggio Imperiale (Foggia): caratteri stratigrafici ed implicazioni paelogeografiche. Il Quaternario, 14, 173-186. 
Rook L., AbBazzi L. \& ENGesser B. (1999) - An overview on the Italian Miocene land mammal faunas. In: Agustì J., Rook L. \& Andrews P. (Eds.), Hominoid Evolution and Climatic Change in Europe. The Evolution of Neogene Terrestrial Ecosystems in Europe, 1, 191-204, Cambridge Press.

Rook L., Gallai G. \& Torre D. (2006) - Lands and endemic mammals in the Late Miocene of Italy: constrains for paleogeographic outlines of Tyrrhenian area. Palaeogeogr., Palaeoclim., Palaeoecol., 238, 263-269.

Rustioni M., Mazza P., Azzaroli A., Boscagli G., Cozzini F., Di Vit E., Masseti M. \& PISANO A. (1993) - Miocene vertebrate remains from Scontrone, National Park of Abruzzi, Central Italy. Rend. Acc. Lincei, 3, 227-237.

SAla B. \& MASInI F. (2007) - Late Pliocene and Pleistocene small mammal chronology in the Italian peninsula. Quatern. Internat., 160, 4-16.

Santangelo N., Ciampo G., Di Donato V., Esposito P., Petrosino P., Romano P., Russo Ermolli E., Santo A., Toscano F. \& VILLA I. (2010) - Late Quaternary buried lagoons in the northern Campania plain (southern Italy): evolution of a coastal system under the influence of volcano-tectonics and eustatism. Ital. J. Geosci. (Boll. Soc. Geol. It.), 129 (1), in press.

SAVAzzi E. (1995) - Parasite-induced teratologies in the Pliocene bivalve Isognomon maxillatus. Palaeogeogr., Palaeoclimat., Palaeoec., 116, 131-139.

SWIERCZEWSKA-GLADYSZ E. (1994) - Some balanid cirripeds from the Korytnica Basin (Middle Miocene; Holy Cross Mountains, Central Poland). Acta Geol. Pol., 44, 97-115.

Sgarrella F., Barra D. \& Improta A. (1985) - The benthic foraminifers of the Gulf of Policastro (southern Thyrrenian Sea, Italy). Boll. Soc. Nat. Napoli, 92, 67-114.
Sgarrella F. \& Moncharmont-Zei M. (1993) - Benthic foraminifera of the Gulf of Naples (Italy): systematics and autoecology. Boll. Soc. Paleont. It., 32, 145-264.

Spalluto L. \& Moretti M. (2006) - Evidenze di neotettonica (Pliocene medio-Pleistocene superiore) nel settore occidentale del promontorio del Gargano (Italia meridionale). It. Journ. Quatern. Sciences, 19, 143-154.

SPAlluto L. \& PIERI P. (2008) - Carta geologica delle unità carbonatiche mesozoiche e cenozoiche del Gargano sud-occidentale: nuovi vincoli stratigrafici per l'evoluzione tettonica dell'area. Mem. Descr. Carta Geol. It., 77, 147-176.

SPROVIERI R. (1992) - Mediterranean Pliocene biochronology: a high resolution record based on quantitative planktonic foraminifera distribution. Riv. Ital. Paleont. Strat., 98, 61-100.

SPROVIERI R. (1993) - Pliocene-Early Pleistocene astronomically forced planktonic foraminifera abundance fluctuations and chronology of Mediterranean calcareous plankton bio-events. Riv. Ital. Paleont. Strat., 99, 371-414.

Tema E., Lanza R. \& Pavia G. (2009) - Paleomagnetic study of the Pirro Nord sedimentary fill. Giornate Paleont. 2009, abstract vol., 56.

Tinti S. \& Piatanesi A. (1996) - Numerical simulations of the tsunami induced by the 1627 earthquake affecting Gargano, southern Italy. Journ. Geodyn., 21, 141-160.

Tondi E., Piccardi L., Cacon S., Kontny B. \& Cello G. (2005) Structural and time constraints for dextral shear along the seismogenic Mattinata Fault (Gargano, southern Italy). Journ. Geodyn., 40, 134-152.

VALLERI G. (1984) - New data on planktonic foraminifera biostratigraphy from the Neogene of the Gargano Peninsula (Foggia, southern Italy). Riv. It. Paleont. Strat., 90, 375-406. 